\title{
School start times and academic achievement - a systematic review on grades and test scores
}

\section{Authors:}

Anna M. Biller ${ }^{1,2^{*}}$, Karin Meissner ${ }^{1,3}$, Eva C. Winnebeck ${ }^{1 \#} \&$ Giulia Zerbini ${ }^{4 *}$

*corresponding authors

\section{Affiliation:}

${ }^{1}$ Institute of Medical Psychology, Ludwig Maximilian University Munich, Munich, Germany

${ }^{2}$ Graduate School of Systemic Neuroscience, LMU Munich, Germany

${ }^{3}$ Division of Health Promotion, Hochschule Coburg, University of Applied Sciences \& Arts, Coburg, Germany

${ }^{4}$ Department of Medical Psychology and Sociology, University of Augsburg, Augsburg, Germany

\# current affiliation: Neurogenetics, Technical University Munich, and Institute for Neurogenomics, Helmholtz Center Munich, Munich, Germany

\section{Contact information:}

anna.biller@med.uni-muenchen.de

Institute of Medical Psychology, Goethestrasse 31, 81373 Munich, Germany

giulia.zerbini@med.uni-augsburg.de

Department of Medical Psychology and Sociology, Stenglinstraße 2, 86156 Augsburg, Germany 
medRxiv preprint doi: https://doi.org/10.1101/2021.05.19.21252346; this version posted May 20, 2021. The copyright holder for this preprint

(which was not certified by peer review) is the author/funder, who has granted medRxiv a license to display the preprint in perpetuity.

It is made available under a CC-BY-NC-ND 4.0 International license .

\begin{abstract}
School start times have been at the centre of many scientific and political debates given the accumulating evidence that bell times are generally too early, and thus lead to an epidemic of sleep restriction in the student population. Recent media attention has conveyed the message that later school starts not only improve sleep but also result in better academic achievement. Several studies have been recently published on this topic requiring a comprehensive review of the results to clarify the relationship between later school start times and academic achievement to inform the general public and policy makers.
\end{abstract}

To this end, we conducted a systematic review of the current literature on school starting times and academic achievement in middle and high school students, considering grades and standardised test scores as achievement measures. We followed the PRISMA guidelines for searching, including, and reporting relevant literature and identified 21 studies for detailed analysis. Evidence quality of included studies was assessed with a pre-defined risk of bias assessment using modified items from the GRADE scheme and ROBINS-I tool.

About half of the reviewed studies reported no (positive or negative) effect of delaying school times on grades and test scores, while the other half reported either mixed or positive results. Given the strong heterogeneity of included studies, we grouped them according to various characteristics, such as academic outcomes, dose of delay, evidence quality, or study design to identify potential hidden effects. Despite this, we could not identify any generalisable effect beyond single studies as to whether delaying school times has clear beneficial effects on academic performance.

Given that grades and scores determine future career trajectories and predict future success, the question whether school start times contribute to academic achievement is of great interest for the general public and needs to be further clarified. Mechanistically, it is very likely that improved sleep leads to or mediates improved cognitive performance and learning, but definitive conclusions on whether this also translates into better grades and scores across all students requires better evidence at this stage. Importantly, this does not preclude other positive outcomes of later start times such as improved sleep (quality), motivation or learning but draws attention on current gaps and shortcomings. To this end, we also highlight critical methodological aspects and provide suggestions to increase the evidence-level and to guide the direction of research in future studies.

Keywords: school starting times, academic performance, grades, scores, adolescence, sleep 
medRxiv preprint doi: https://doi.org/10.1101/2021.05.19.21252346; this version posted May 20, 2021. The copyright holder for this preprint

(which was not certified by peer review) is the author/funder, who has granted medRxiv a license to display the preprint in perpetuity.

It is made available under a CC-BY-NC-ND 4.0 International license .

\section{Introduction}

Early school start times (SSTs) have been recognized as one of the leading causes of inadequate sleep in teenagers worldwide. They clash with the longer and later sleep needs of teenagers ${ }^{\text {e.g. }}{ }^{1-4}$, leading to wide-spread, chronic sleep restrictions in the student population ${ }^{\text {e.g. 5-8. }}$. Because of the accumulating evidence that sleep restriction is detrimental for psychological ${ }^{9-11}$ and physical health ${ }^{12,13}$, some schools (mainly in the US) have delayed their SSTs during the past decades.

Several studies - although mostly short-term and cross-sectional - have documented the beneficial effects of delaying SSTs on sleep duration and daytime sleepiness (as reviewed in ${ }^{14-16}$ ). More recently, other outcomes with regards to SSTs have been investigated, such as cognitive and academic performance. Since short sleep has been linked to detrimental effects on learning, memory, and cognition ${ }^{17-23}$, it is fair to hypothesize that delaying SSTs could result in better academic achievement (e.g. as measured in grades or scores) mediated by longer sleep duration, improved sleep quality or better circadian alignment.

However, early findings from field studies on this topic are very heterogenous, likely due to methodological differences in outcome variables and study designs ${ }^{24,25}$. For instance, academic achievement has been operationalised in different ways (e.g. self-reported grades, single final grades, grade point averages, standardised test scores) and with different scales. In addition, study designs vary considerably across studies, and achievement is influenced by many student- and school-level factors ${ }^{\text {e.g. }}$ 26-30

Previous reviews have mostly summarized the effects of delaying SSTs on several different variables (e.g., sleep, tardiness rates, absences, motor vehicle accidents and health ${ }^{14,16,25}$ ). We identified a total of 12 peer-reviewed reviews ${ }^{15,16,37,38,24,25,31-36}$ - only 3 of them systematic reviews ${ }^{15,16,34}$ - that discuss SSTs in relation to academic achievement. However, all of them cover the topic only broadly or on the side, so that no unifying conclusion can be drawn from the existing reviews to date. Despite this lack in systematic reviews and meta analyses, newspaper articles often purport it as established scientific fact that later SSTs improve academic achievement ${ }^{39-41}$, while some public outreach programs also convey this message ${ }^{42}$, mostly referring to single studies that found positive associations.

Since academic achievement shapes future career trajectories ${ }^{43-45}$, answering the question whether delaying SSTs improves achievement goes beyond simple and genuine scientific curiosity - a rigorous and up-to-date analysis of the accumulating evidence is warranted. Following the PRISMA guidelines for systematic reviews and including a detailed risk-of-bias assessment based on items from the GRADE scheme ${ }^{46}$ and the ROBINS-I too ${ }^{47}$, we addressed the specific gaps in the review literature to date, such as a particular need for discussion of the quality of evidence, a detailed description of the outcome variables and statistical analyses, and a distinction between middle/high school and college students, who differ considerably in their sleep characteristics and class schedules. In our review, we thus systematically assessed the existing evidence on SST effects on academic achievement via studies on course grades or standardised test scores in middle and high school students. We provide both a summary as well as detailed descriptions of each included study, assess the overall and individual evidence level and highlight critical points for future research. 
medRxiv preprint doi: https://doi.org/10.1101/2021.05.19.21252346; this version posted May 20, 2021. The copyright holder for this preprint

(which was not certified by peer review) is the author/funder, who has granted medRxiv a license to display the preprint in perpetuity.

It is made available under a CC-BY-NC-ND 4.0 International license .

\section{Methods and Materials}

\section{Literature search}

Our focused question was whether changes in school start times in middle or high schools (or international equivalents) have any effect on academic achievement as measured in (standardised) test scores or course grades (both subjectively and objectively reported). Therefore, we conducted a systematic electronic literature search in Web of Science and PubMed via Endnote (version 9.3.1), and an online search on SCOPUS in August 2020, which was updated in November 2020. All languages, article types or year of publications were allowed. The following search terms were used (in title, abstract or keywords):

school start times OR school start time OR school starting times OR school start delay OR start late OR start early

AND

grades OR school performance OR academic performance OR test scores OR standardised scores OR achievement

Additionally, reference lists of previous reviews and articles were scanned to ensure complete retrieval. We included two unpublished articles that are currently under review in peer-reviewed journals ${ }^{48,49}$. The PRISMA flowchart (Fig. 1) was followed to adhere to preferred reporting guidelines for systematic reviews ${ }^{50}$.

\section{Study selection criteria}

All duplicate retrievals were removed via the Endnote duplicate function followed by a manual search and deletion round. All remaining titles and abstracts were subsequently screened on relevance with regards to the focused question. Full articles were then searched if the following study selection criteria were fulfilled: academic achievement was assessed as grades or (standardised) test scores; participants were middle school or high school students; articles included both a change/variation in SSTs and a measure of academic achievement (course grades or standardised test scores).

\section{Data abstraction and analysis}

The recommended PRISMA guidelines for data synthesis and systematic reviews were followed ${ }^{50}$. AMB and GZ independently and systematically extracted pre-defined study characteristics as per Figure 1. The 21 studies included in the final qualitative synthesis were grouped by their study design. Please note that we grouped according to the design underlying the grade or test score outcomes, which can differ from the design for other outcomes investigated in the respective study such as sleep duration. Identified designs were: longitudinal designs with control group, longitudinal designs without control group, and cross-sectional designs. Note that a longitudinal design means that the same students were followed over several time points (within-subject comparisons) whereas a cross-sectional design compares different students either at one time point or between time points (between-subject comparisons). It was noticed that several cross-sectional studies described their design as longitudinal because they followed the same schools or districts over several time points (which might or might not include the same students); we considered these studies as repeated cross-sectional studies based on 
medRxiv preprint doi: https://doi.org/10.1101/2021.05.19.21252346; this version posted May 20, 2021. The copyright holder for this preprint (which was not certified by peer review) is the author/funder, who has granted medRxiv a license to display the preprint in perpetuity.

It is made available under a CC-BY-NC-ND 4.0 International license .

their study design and statistical analysis. Authors were contacted when information was missing, not clearly defined or further analyses were available upon request. If authors responded, information was updated accordingly. If authors did not answer or failed to provide necessary information in the original article, this was marked as "not available" ("NA") in Tab. S1 and, and flagged orange or red (depending on the severity) in the reporting bias category of the risk of bias assessment (Tab. 1).

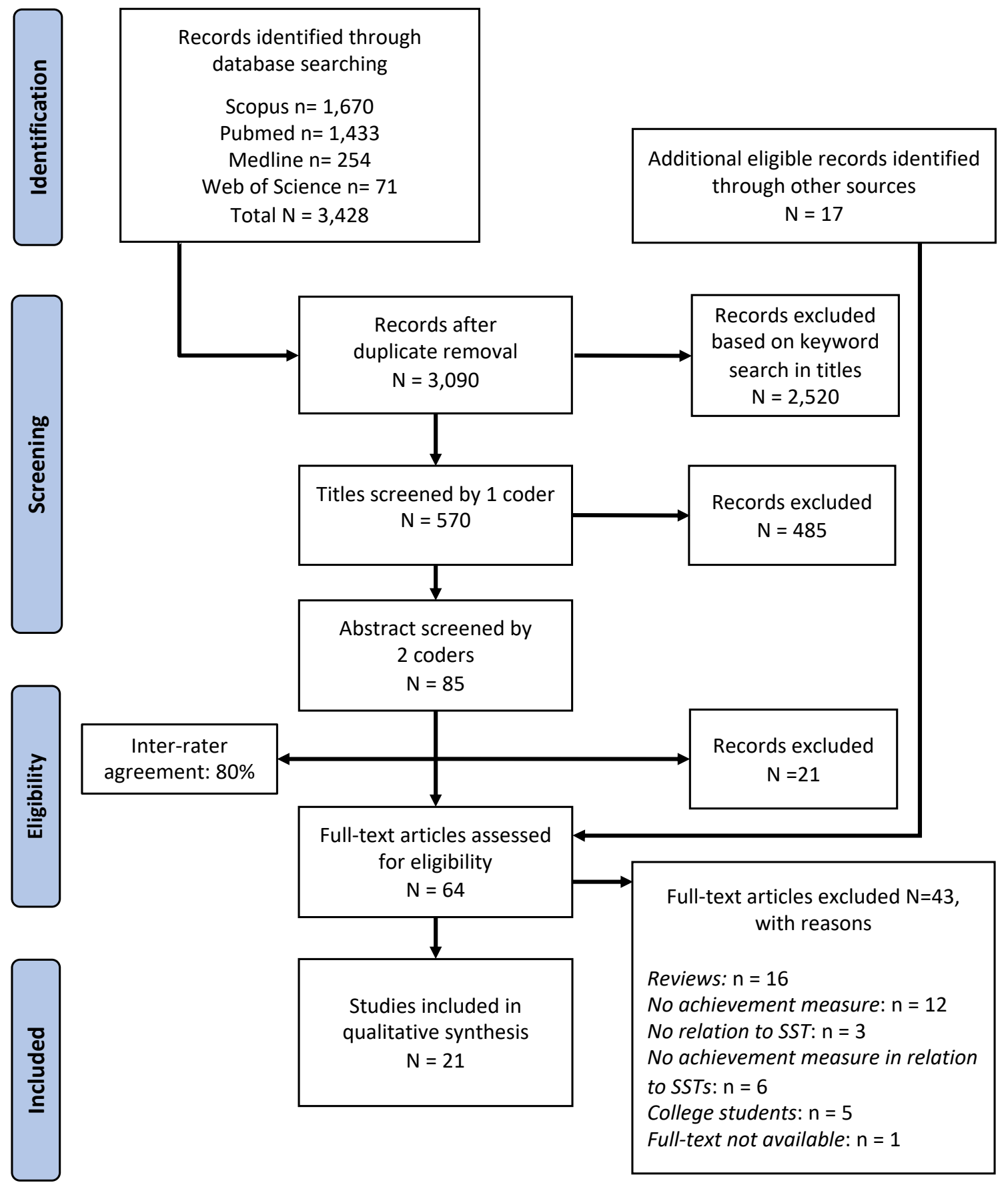

Fig. 1 | PRISMA flowchart. The PRISMA flow diagram for our systematic review process detailing the database searches, the number of identified records, titles and abstracts screened, the final studies included in qualitative synthesis and reasons for exclusion of studies. 
medRxiv preprint doi: https://doi.org/10.1101/2021.05.19.21252346; this version posted May 20, 2021. The copyright holder for this preprint

(which was not certified by peer review) is the author/funder, who has granted medRxiv a license to display the preprint in perpetuity.

It is made available under a CC-BY-NC-ND 4.0 International license .

\section{Risk of bias assessment}

A pre-defined risk of bias assessment was conducted independently by AMB and GZ (Tab 1). Given that there were no randomised controlled trials (RCTs) in the final sample and the large methodological differences between studies, bias assessment guidelines were adapted as there are no standard guidelines for non-RTCs. To this end, items from the GRADE scheme ${ }^{46}$ and ROBINS-I tool ${ }^{47}$ used for nonRTCs were included and modified. Each study was evaluated on the following bias categories and flagged green (low risk), orange (intermediate risk) or red (high risk):

Selection bias (randomisation): Participants were not randomly assigned to the control group or the treatment group. Non-RTC are high risk by definition.

Allocation concealment: Researchers did not know the sequence or method of randomisation and hence could not predict the next allocation. Non-RTC are high risk by definition.

Reporting bias on author level: Authors did not report or only partially reported all outcome variables, sources of outcomes, statistical analyses or general information necessary to judge the study. When a publication stated that information was available upon request, the authors were contacted.

Responder bias on student level: Students could be biased when self-reporting, which is not the case for objectively reported grades or scores provided by official sources (e.g. the registry or state level administrations).

Performance bias (blinding of participants/personnel): Participants who knew that they took part in a study are prone to behavioural changes (Hawthorne effect). If informed consent was obtained, students were considered unblinded, else they were blinded. This also covers a potential self-selection bias towards taking part in a study.

(Dis)similarity of baseline characteristics: Authors checked and reported the (dis)similarity of baseline characteristics between cross-sectional groups or between control and treatment groups.

Appropriate statistical models: Statistical analyses accounted for confounders and were appropriate for the given study design.

Cohort bias (control group present): Longitudinal changes might be due to cohort characteristics and not due to an intervention when no control group was present. Only applies to longitudinal studies.

Tab. S1 lists the decision criteria underlying the risk of bias assessment. In cases where the assessment differed between $A M B$ and $G Z$, mutual agreement was sought after discussion of critical points. In case no agreement could be reached, two independent scorers (ECW and KM) evaluated the respective studies and a consensus was found across all scorers. From the assessment, a total quality-of-evidence score was calculated as follows: scores for each bias category were added up (green contributed 1 point, orange 0.5 points and red 0 points) and then divided by the maximal possible score ( 8 for the longitudinal studies with control group, 7 for the longitudinal studies without control group, and 7 points for cross-sectional studies). The quality-of-evidence score was the proportion (\%) of the maximum score (e.g. 6 out of $\max 8$ points $=75 \%$ ). The different bias categories were not weighted. We defined scores $<25 \%$ as low, $\geq 25 \%$ and $<75 \%$ as moderate and $\geq 75 \%$ as good. 
medRxiv preprint doi: https://doi.org/10.1101/2021.05.19.21252346; this version posted May 20, 2021. The copyright holder for this preprint (which was not certified by peer review) is the author/funder, who has granted medRxiv a license to display the preprint in perpetuity. It is made available under a CC-BY-NC-ND 4.0 International license .

\section{Results}

\section{Literature search}

A total of 3,428 articles were identified based on the automated search in title, abstract and keywords, of which 3,090 remained after duplicate removal (Fig. 1). Due to this large number, a second automated search was carried out on titles only, resulting in 570 articles. One coder (AMB) then screened titles excluding 485 manually due to irrelevant titles. The abstracts of the remaining 85 studies were screened by both coders (AMB and GZ), who agreed on 47 studies (80\% inter-rater agreement) and additionally identified 17 studies through reference lists of included studies. The identified 64 articles were subsequently screened in full by both coders, 43 excluded based on the pre-defined exclusion criteria and 21 ultimately included in the qualitative synthesis (Fig. 1).

\section{Study characteristics and quality}

In the following paragraphs, summary information concerning all included studies are reported (see also Fig. 2 and Tab. 2).

\section{School type and cohort characteristics}

The majority of studies collected data in high schools (>900 schools), of which 2 were also boardingschools $51,52,2$ grammar schools and 2 vocational schools ${ }^{53}$. Other school types were middle schools $(>140)$ and elementary schools (85, not considered here). In one study, school type was not specified ${ }^{54}$. The sample sizes varied drastically between 157 to >770,000 individual students and up to >1 Mio number of observations (e.g. individual grades). However, some authors did not distinguish between number of individuals, number of schools and number of observations. In 13 studies, age of participants was reported and ranged approximately between 11-19. Most studies were conducted in the US $(13)^{51,52,62-64,54-61}$, followed by South Korea $(4)^{48,65-67}$, Germany ${ }^{49}$, Croatia ${ }^{53}$, England ${ }^{68}$, and one unknown location $^{69}$ (Fig. 2a and Tab. 2). Gender ratios, ethnicity/race and a proxy for socioeconomic status (SES; free or reduced lunch eligibility) were not consistently reported.

\section{Study designs}

We identified longitudinal (within-subject) and cross-sectional (between-subject) studies. The 11 longitudinal studies all included a change in SSTs and hence had an intervention group 48,49,67,51,52,55-57,64-

66. However, only 6 studies had an additional control group with no change ${ }^{48,56,65-67}$ or advance of SSTs ${ }^{55}$ (Fig. 2b). Of the cross-sectional studies, 4 studies compared schools in various districts without an intervention but based on their different school start times ${ }^{53,58,61,69}$. The rest included a change in SST, providing mostly repeated cross-sectional comparisons of schools or districts over roughly one ${ }^{60}$ or several years ${ }^{54,59}$, or at one time point after the change ${ }^{62,63}$. One cross-sectional study also had an A-BA design, in which the school start delay during phase $B$ was abolished to return to baseline start time (A) after 2 years ${ }^{68}$.

\section{Statistical analyses}

A vast range of different statistical analyses was reported (Tab. S1 and Fig. 2c). Notably, regressions were the dominant analysis method, ranging from general OLS regressions $54,55,58,59,65$, quantile 
medRxiv preprint doi: https://doi.org/10.1101/2021.05.19.21252346; this version posted May 20, 2021. The copyright holder for this preprint

(which was not certified by peer review) is the author/funder, who has granted medRxiv a license to display the preprint in perpetuity.

It is made available under a CC-BY-NC-ND 4.0 International license .

regression ${ }^{55}$, difference-in-difference methods ${ }^{48,56,65,67}$ and binomial regression ${ }^{60,66}$ to linear mixed models ${ }^{49,57}$ and path analysis with probit regression ${ }^{69}$. One study reported Oster models with bounded effects and instrumental estimates ${ }^{58}$. Another study used MANOVA ${ }^{61}$, while several simpler analysis methods not controlling for covariates were also used. These were t-tests ${ }^{57,63,68}, X^{2}$-tests ${ }^{52}$, MannWhitney Test $^{53}$ and correlations ${ }^{63}$. Notably, several studies did not report statistical analyses ${ }^{51,62,64}$.

a Study site

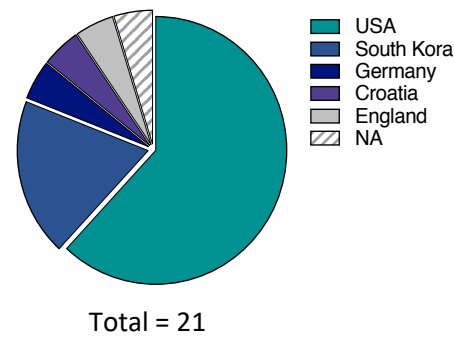

Total $=21$

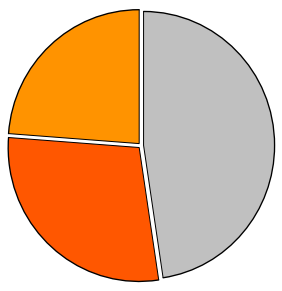

Total $=21$
C Statistical analysis

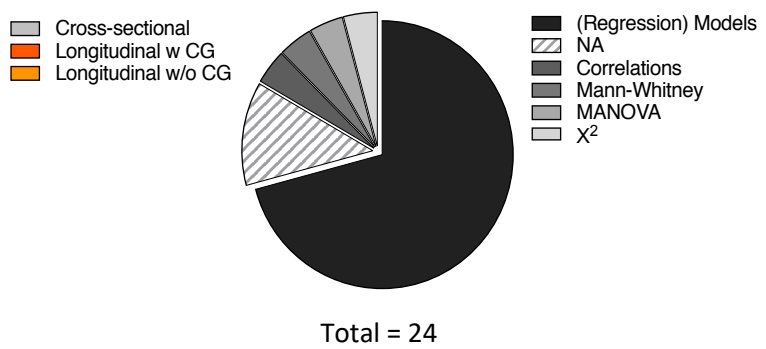

e

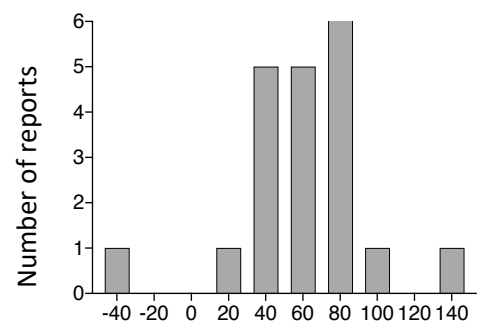

Maximal change in school start times $(\mathrm{min})$

Fig. 2 | Characteristics of included studies. a-d, Pie charts depicting key characteristics of the 21 studies included in the final review. Since several studies used multiple types of analysis or assessed multiple outcomes, the total number in c,d is $>21$. e, Histogram displaying the magnitude of the school start changes reported in the 21 studies. When a study reported ranges, the maximum of the range was taken. Please note that these numbers therefore just provide a rough overview and are not precise. Abbreviations: NA, not available; w, with; w/o, without; CG, control group; GPAs, grade point average; ACT, American College Test; GCSE, General Certificate of Secondary Education; PLAN, a preliminary ACT test discontinued in 2014.

\section{Study outcome measures}

About half of the studies provided grades as outcome measures, while the other half provided (standardised) test scores. However, since some studies did not provide explanations whether scores originated from standardised tests, a clear distinction between course grades and test scores was not always possible. Clearly defined scores were ACT scores (American College Test) ${ }^{54,56,59}$, national achievement scores or PLAN scores ${ }^{63}$, standardised test scores from Regents Exams ${ }^{57}$, standardised endof-course exams ${ }^{59}$, annual national assessment of achievement in South Korea ${ }^{67}$, GCSE in the UK (General Certificate of Secondary Education) ${ }^{68}$, and Woodcock-Johnson Revised Test of Basic Achievement scores ${ }^{58}$, all of which were objectively reported (except for Groen et al., for which the source was unclear ${ }^{58}$ ) (Fig. 2d). The remaining studies analysed other types of objective scores or grades $48,49,55,59,61,64,65$, subjective grades ${ }^{51,52,60,62,63,66,69}$, and in one study the outcome was unclear ${ }^{53}$. Sampling resolution was mostly once per year, the highest reported resolution was once per academic quarter ${ }^{49}$. 
medRxiv preprint doi: https://doi.org/10.1101/2021.05.19.21252346; this version posted May 20, 2021. The copyright holder for this preprint (which was not certified by peer review) is the author/funder, who has granted medRxiv a license to display the preprint in perpetuity. It is made available under a CC-BY-NC-ND 4.0 International license .

\section{Amount of school start time change and duration of exposure to the new start time}

The SST delay reported was on average $64 \mathrm{~min}$ (median=60, SD=26) with a range of 25-135 min (Fig. 2e). This average is based on the maximal delay reported by each study (several reported multiple amounts) and thus an approximation. Since some studies only provided SST ranges or a minimal start delay, the numbers are not precise. In 2 studies, SSTs were actually advanced by 40 min and 25-45 min respectively ${ }^{5,56}$. One study changed to a flexible SSTs in which students could choose daily whether to attend school at 8:00h or 8:50h ${ }^{49}$. Exposure duration to the (new) start time ranged from as little as 3 months to 7 years (Tab. 2). However, several studies did not clearly state the timeframe (so we inferred where possible), or did not test a change but a difference in start times across schools.

\section{Summary of individual study results}

In the following, we shortly report findings of individual studies, grouped by study design. In summary, 5 studies found clear positive effects of delayed school starts on academic achievement ${ }^{48,55,62,68,69}, 5$ reported mixed effects ${ }^{58,59,61,63,67}, 9$ did not detect significant effects ${ }^{49,51,52,54,56,57,64-66}, 1$ reported negative effects ${ }^{53}$, and one study's finding was unclear ${ }^{60}$ (Fig. 3b). Regarding SST advances, 1 study reported negative effects ${ }^{69}$, while another did not ${ }^{56}$.

Notably, of the 21 studies, 4 studies investigated the same 9 o'clock policy in South Korea ${ }^{48,65-67}$. Although they considered partly different outcomes and schools (middle vs high schools), the Korean studies likely analysed data from overlapping students, hence this cannot be regarded as entirely independent evidence. The same may apply to 2 studies by Wahlstrom et al. conducted in the same district: the report in $2002^{64}$ might be a longitudinal follow-up of the report from $1997^{62}$, but we were unable to confirm this.

\section{Longitudinal studies with control group}

Edwards (2012) (55 $^{5}$ followed several middle schools in Wake County, North Carolina (USA), over 8 years (up to $N_{\text {observations }}>102,000$ ) during which 9 schools delayed, 4 advanced and 11 did not change their SSTs. The authors analysed objective standardised end-of-year test scores in reading and math via regression models with pooled OLS models and accounted for various covariates both on the student and school level. They found that a $1 \mathrm{~h}$ later school start corresponded to a 1.8-2.9 percentile increase in math (0.06-0.07 SD) and 1.0-3.6 increase in reading (0.04-0.05 SD) when adjusted for covariates (both significant), and that the effect was stronger for lower achieving students.

Jung $(2018)^{65}$ followed 85 elementary and 63 middle schools $\left(N_{\text {students }}>4,000\right)$ in South Korea 3 years prior to and 2 years after a delay from 8:00h-8:20h to 9:00h. Participants were recruited as part of the Gyeonggi Education Panel Study and their objective Korean, English and math course grades were reported. The author found no effect of delaying SSTs on grades in the longitudinal within-subject comparison with the control group (difference-in-difference estimation/OLS estimation). Crosssectional analyses as robustness check confirmed the longitudinal results. Similar to Kim ${ }^{67}$ and Biller et $a l .{ }^{49}$, the author also found that when not controlling for covariates, test scores increased, while the effect became statistically non-significant when covariates were added. 
medRxiv preprint doi: https://doi.org/10.1101/2021.05.19.21252346; this version posted May 20, 2021. The copyright holder for this preprint

(which was not certified by peer review) is the author/funder, who has granted medRxiv a license to display the preprint in perpetuity.

It is made available under a CC-BY-NC-ND 4.0 International license .

$\operatorname{Kim}(2018)^{67}$ also compared high schools from two districts in South Korea $\left(\mathrm{N}_{\text {students }}>2,000\right)$, of which Gyeonggi adopted a 9 o'clock start time policy. Pre-change SSTs in this district ranged from 7:40h-9:00h and were delayed to 9:00h post-change, while Seoul did not change (control group). The author used the difference-in-difference method and mixed within-between regression models to estimate the influence of the 9 o'clock policy on the objective Annual National Assessment of Educational Achievement for $9^{\text {th }}$ and $11^{\text {th }}$ graders, and the College Scholastic Ability Test (CSAT) for $12^{\text {th }}$ graders (data cover 5 years pre and 2 years after the change). Only male $11^{\text {th }}$ graders showed a significant increase of 0.06-0.08 SD for math, even after adjusting for confounders. CSAT scores did not increase significantly with the 9 o'clock policy.

Similarly, Rhie and Chae (2018) ${ }^{66}$ studied middle and high schools in 4 South Korean districts, of which Gyeonggi delayed SSTs (baseline from a range of 7:30h-8:10h) to 9:00h, while Daegu, Gyeongbuk and Ulsan did not change (SSTs ranged from 7:30h to 8:00h; control group). Based on logistic regression analysis in their large sample $\left(\mathrm{N}_{\text {students }}>42,000\right)$, they found that self-reported GPAs increased year by year in both the intervention and the control group (data cover 2 years pre and after the change; adjustments for covariates not reported).

Shin (2018) ${ }^{48}$ is the fourth study that investigated the South Korean 9 o'clock policy effects in Gyeonggi (change in SST from around 8:20h to 9:00h), compared to Seoul (control group), but the author used objective semester grades as outcome and focused on middle schools ( $N_{\text {observations }}>33,000$ ). The data span 2 years and was analysed using the difference-in-differenced method, which accounted for various individual and school-level variables. Shin reported a 0.03 SD increase in math and 0.02 SD increase in reading grades when adjusted for time trending (both significant).

Lenard et al. (2020) ${ }^{56}$ looked at 19 high schools in Wake Country, North Carolina, USA, of which 5 had advanced their SSTs from 8:05h to 7:25h, while the control group (14 high schools) kept their start at 7:25h. They found no significant change in objective standardised American College Test (ACT) scores, neither in their longitudinal nor their cross-sectional comparison of about $\mathrm{N}_{\text {students }} \sim 10,000$ in 8 cohorts. The authors used a difference-in-difference approach and comparative interrupted series controlling for various individual and school-level variables. Their data spanned 4 years prior and 7 years after the change.

\section{Longitudinal studies without control group}

Biller et al. (2021) ${ }^{49}$ investigated in a German secondary school the effects of a unique SST change, the introduction of flexible SSTs, on objective, quarterly grades for up to 2.5 years prior to and 1.5 years after the change. In the flexible system, students chose daily whether to attend school at 8:00h or 8:50h after starting predominantly at 8:00h in the conventional system before. Longitudinal linear mixed model analyses of 16,724 grades in 12 academic subjects $\left(N_{\text {students }}=157\right)$ indicated that the flexible system did not affect grades when accounting for several student and school-level factors.

Boergers et al. (2014) $)^{51}$ studied an independent high school (boarding school) in Rhode Island, USA, that delayed its start time from 8:00h to 8:25h ( $\left.\mathrm{N}_{\text {students }}=197\right)$. The percentage of students who reported to obtain "mostly Bs or better" changed from 93\% to 91\% after 2 months, however statistical analyses were not reported. 
medRxiv preprint doi: https://doi.org/10.1101/2021.05.19.21252346; this version posted May 20, 2021. The copyright holder for this preprint

(which was not certified by peer review) is the author/funder, who has granted medRxiv a license to display the preprint in perpetuity.

It is made available under a CC-BY-NC-ND 4.0 International license .

Owens et al. (2010) ${ }^{52}$ used the same outcome variable as Boergers et al. ${ }^{51}$ in their study of $\mathrm{N}_{\text {students }}=201$ from an independent high school (boarding and day school) in Rhode Island, USA, over 6 months (3 time points of assessment). They found that a school start delay from 8:00h to 8:30h was associated with a non-significant increase of students reporting to obtain "mostly Bs or better" ( $82 \%$ pre vs $87.1 \%$ post, using a $\chi^{2}$ test). Adjustment for covariates was not reported.

Thacher \& Onyper (2016) $)^{57}$ studied $\mathrm{N}_{\text {students }}$ 800 from one public high school in Glen Falls, NY, USA, which delayed their SSTs from 7:45h to 8:30h. They used mixed effect analyses to analyse longitudinal effects ( 2 years before and 2 after the change), adjusting for multiple covariates and including moderator effects. This analysis indicated no systematic effect on subjectively reported GPAs (0-100\%) nor subjectspecific GPAs or standardised test scores (Regents exam). They did find positive effects for $11^{\text {th }}$ graders' overall GPAs, however, only when they ran cross-sectional comparisons (increase from $78.79 \%$ to 81.34\%). In contrast, no systematic effects on individual academic subjects were found in this crosssectional analysis. In fact, 2 out of 20 subjects were significantly worse after the change and also Regents exam scores decreased significantly.

Wahlstrom (2002) ${ }^{64}$ investigated the effect of later SSTs in 7 high schools in Minneapolis, Minnesota, USA, for 3 years before and after the change from a 7:15h to an 8:40h-start. The study analysed objective letters grades and found small improvements that were not statistically significant. However, no actual numbers (or the letter grade scale), nor any statistical test were reported.

\section{Cross-sectional studies}

Groen and Pabilonia $(2019)^{58}$ studied $N_{\text {students }}=1200$ from a sample of 790 U.S. high schools and reported that a $1 \mathrm{~h}$-delay in high school start times was associated with significantly increased reading scores (but not math scores) by 0.16 SD for females, while no significant effect was found for males. The authors used OLS models, including many covariates (individual, family, high school, and community characteristics) that were added sequentially to the models. Data were collected for 2 years, sampled once per year.

Hinrichs $(2011)^{54}$ found no association between SSTs and ACT scores ( $\left.N_{\text {students }}>196,000\right)$ after a delay of 85 minutes from 7:15 to 8:40 AM in 73 schools in Minneapolis, USA, when accounting for various student-level and district level covariates and the length of the school day using OLS regression models (9 years of data). In a similar analysis, the author also found no effect on Kansas assessment scores in reading, maths, science, and social disciplines including all public high schools in Kansas (1,666 schools; up to 5 years of data). In another sample of 75 schools in 19 districts in Virginia, USA, again no association was found between delayed SST and test scores in standardised end-of-course exams ( 8 years of data).

Bastian and Fuller $(2018)^{59}$ analysed 4 years of data from $\mathrm{N}_{\text {students }}>770,000$ in 410 high schools in North Carolina, USA, of which 23 changed their start times ( 9 schools by $\geq 30 \mathrm{~min}$ ). The authors tested both the influence of a linear SST delay per $1 \mathrm{~h}$ and a categorised school start depending on actual start time i) on overall and $1^{\text {st }}$ period course grades, ii) standardised end-of-course exams, and iii) ACT scores. Linear regression models adjusting for several student and school-level covariates showed that only a start at 8:30h or later was associated with significant improvements of 0.05 SD in $1^{\text {st }}$ period course 
medRxiv preprint doi: https://doi.org/10.1101/2021.05.19.21252346; this version posted May 20, 2021 . The copyright holder for this preprint (which was not certified by peer review) is the author/funder, who has granted medRxiv a license to display the preprint in perpetuity. It is made available under a CC-BY-NC-ND 4.0 International license .

grades. Importantly, this was one of the only studies that particularly focused on specific subgroups of students: especially low-performers, students with a minority background and with a low SES benefitted from later starts (0.05-0.07 SD in course grades and up to 0.28 SD in ACT composite scores per $1 \mathrm{~h}$ ).

Dunster et al. (2018) ${ }^{60}$ reported results from a cross-sectional pre-post comparison of a one-semester biology course grade from 2 high schools in Seattle, USA, which delayed their starts from 7:50h to 8:45h. Median grade was $77.5 \%$ in the year before the delay and $82 \%$ in year after the delay $\left(N_{\text {students }}=178, \sim 7-\right.$ month exposure). In logistic regression, where grade was used as a predictor variable (not outcome), an increase in grades significantly increased the odds of a student stemming from the after-delay-cohort rather than from the before-delay-cohort (quantitative results not reported; covariates: school, mood, chronotype, sleepiness and sleep offset time on schooldays). Interpretation of the results is limited by the use of grades as independent variable and adjustment for sleepiness and sleep offset in the analysis.

Milić et al. (2014) (53 $^{53}$ analysed in a one-off assessment the final semester grades of 4 Croatian schools (grammar and vocational schools) with morning and afternoon schedules: 2 schools followed early schedules (alternating between 7:00h and 13:00h), while 2 schools had later schedules (8:00h and 14:00h). Based on the sample of $\mathrm{N}_{\text {students }}=821$ and Mann-Whitney Test (no covariates), it was concluded that students attending the early schedules got significantly better grades ( $72.0 \%$ vs $65.6 \%$ in the laterscheduled schools). An extra caveat of the unadjusted analysis is that the sample in the early scheduled schools consisted of three times more boys and grades often associate with gender (see e.g. Fig 3).

Wolfson et al. (2007) ${ }^{61}$ compared the average fall-quarter grade (0-100\%) of a total of $\mathrm{N}_{\text {students }}=205$ attending either an early middle school (starting at 7:15h) or later middle school (starting at 8:37 AM) in New England, USA. MANOVA results with school, grade and gender as covariates indicated that, after half a year of exposure, $8^{\text {th }}$ graders in the later school obtained significantly better objectively reported grades than their early school peers $(83.79 \%$ vs $76.85 \%)$ while no difference was found for $7^{\text {th }}$ graders.

Lewin et al. (2017) ${ }^{69}$ compared 26 middle schools (unknown location) clustered into 3 groups depending on their SSTs (earliest, early, late). The authors obtained self-reported grades ("mainly As", "mainly Bs", "mainly Cs", "mainly Ds/Fs") and sleep duration from $\mathrm{N}_{\text {students }}>32,000$ in 3 years. Path-analyses with probit regression with grades as outcome, sleep duration as mediator and inclusion of several covariates showed significantly better grade estimates in the late group compared to the earliest group but not the early group. This effect was in a similar magnitude as that of gender (females better than males) and ethnicity (non-whites worse than whites). Free lunch status as a proxy for SES had the greatest predictive value for grades, while the influence of sleep duration as a mediator was smaller but still significant.

Wahlstrom et al. (1997) ${ }^{62}$ compared middle and high schools in three districts in Minnesota, USA, of which District A delayed its start time to 8:30 and Districts B and C stayed with their earlier starts of 7:25h and 7:15h, respectively. The study reports that mean self-reported grades in high schools in district A were highest compared to the other 2 districts, however the scale, statistical analyses and the use of covariates were not reported. Results for middle schools (7-8 ${ }^{\text {th }}$ graders) were comparable but again no statistics were given and absolute differences were marginal.

Kelley et al. (2017) ${ }^{68}$ followed an English high school over 4 years across two changes in SST (A-B-A design): from the standard school start at 8:50h in year 0, to a delayed start at 10:00h for two years, 
medRxiv preprint doi: https://doi.org/10.1101/2021.05.19.21252346; this version posted May 20, 2021. The copyright holder for this preprint

(which was not certified by peer review) is the author/funder, who has granted medRxiv a license to display the preprint in perpetuity.

It is made available under a CC-BY-NC-ND 4.0 International license .

and for another year back to the original start time. For each year, national examination results (GCSE exams, achievement over the past 2 years plus final examination) of a different cohort of students was assessed $\left(N_{\text {students }}>2,000\right)$. As the only study in our selection, the study analysed the achievement of the cohorts not only in comparison to each other but also in comparison to a national benchmark and to an indicator of predicted progress (value-added prediction) based on student cohorts' past achievements. Based on t-tests (no covariates), the study found that delayed SST for two years were significantly associated with an increased percentage of students making good academic progress (i.e., achieving $\geq 5$ GCSE grades of $\geq C$ in English, math and $\geq 3$ other subjects) (from 34\% in year 1 to $52 \%$ in year 3 ) and with a 12-percentage point increase in the value-added number of students. Both improvements were partly reversed after return to the earlier start time.

Wahlstrom et al. (2014) ${ }^{63}$ analysed self-reported grades, objectively reported GPAs, and standardised test scores (state-wide achievement tests or PLAN) from $9-12^{\text {th }}$ graders after a high school start delay from 7:35h-7:50h to 8:00h-8:55h in Minnesota, Colorado, and Wyoming, USA. The study yielded mixed and mostly not-significant effects using t-tests and correlations without considering covariates.

\section{Risk of bias assessment}

To judge the evidence quality of the included studies, we performed a risk of bias assessment (Tab 1). Overall, since none of the studies were RCTs, selection bias was high by definition for all studies. Furthermore, in many studies, basic reporting standards were only partially met (reporting bias), blinding was a high concern in over half of the studies (performance bias), and appropriate statistical models that control for confounders were not used in 7 out of 21 studies. This meant that over half of the studies stayed below $75 \%$ of the good-evidence-score within their respective study design category. Therefore, the quality of the evidence can be deemed only moderate.

On the positive side, especially the longitudinal studies with a control group showed a high evidence quality with $2^{56,65}$ out of 6 studies reaching at least a $75 \%$-score and 3 more studies ${ }^{48,55,67}>50 \%$. Two studies ${ }^{48,67}$ could have improved their score to $75 \%$ simply by ensuring sufficient reporting of outcomes and statistical analyses. Furthermore, all included studies had appropriately large sample sizes (and/or high resolution) and were therefore very likely suited to detect a true effect (sufficient statistical power). 
Tab. 1 | Risk of bias assessment. Included studies are ordered by their study design (used for grade or score analyses) and assessed in different bias categories. Cell colour shows the risk status for the respective bias category (red=high risk; orange=intermediate; green=low risk). Question marks indicate ambiguous information (more details given in Tab. S1). For the final study result based on the obtained evidence score, an upward arrow indicates a positive finding for later school start times on academic achievement, a right arrow indicates mixed findings. Longitudinal studies assess the same individual over time, while cross-sectional studies follow different students. NA, not applicable.

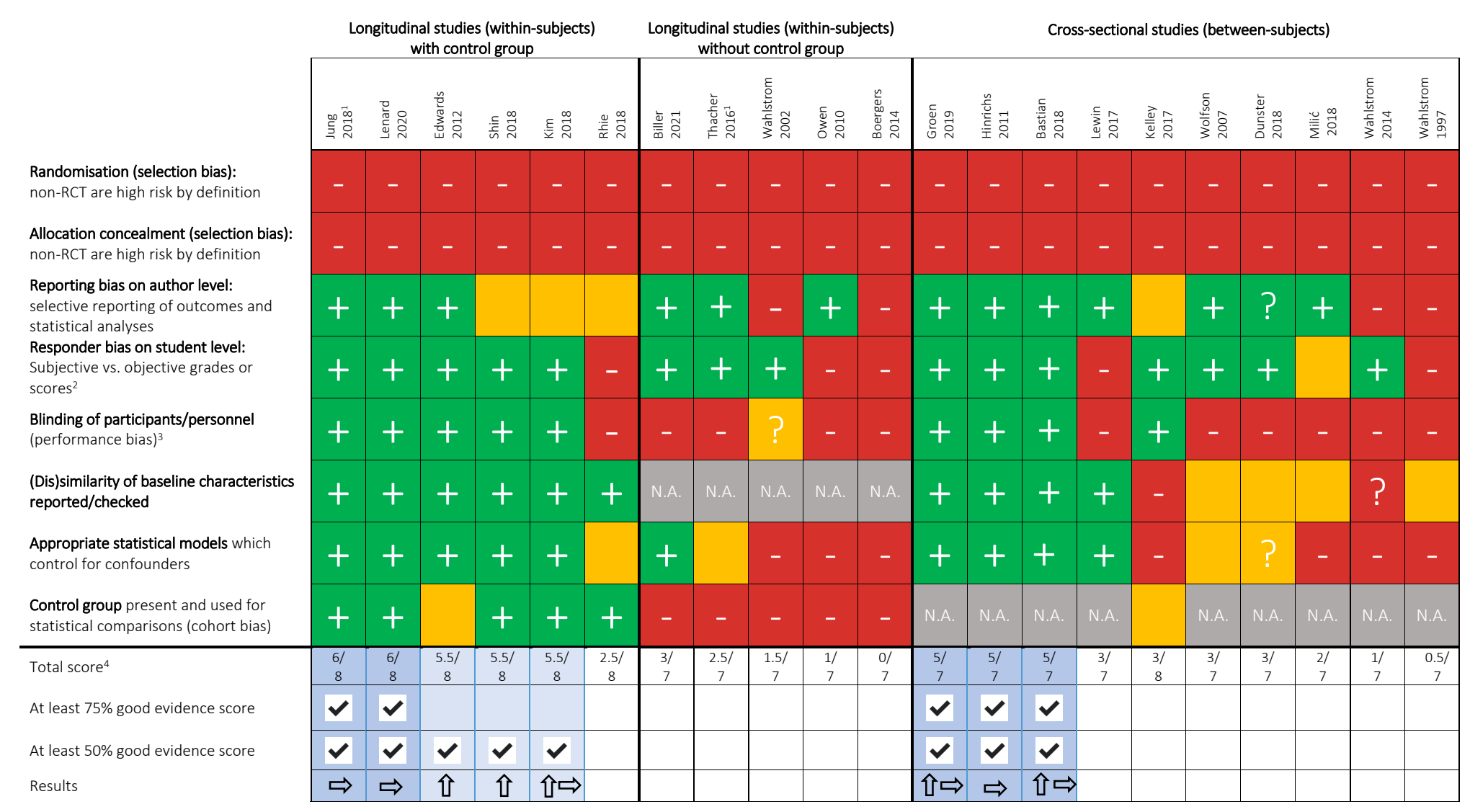

${ }^{1}$ These studies also included a cross-sectional analysis (between-subjects comparison) for their grades or scores analyses; either as a robustness check or as secondary analysis. For results on these see the result section and Tab.2.

${ }^{2}$ Subjective if students themselves reported their grades or scores; objective if the school, registry or any other administration reported the grades or scores.

${ }^{3}$ Blinding refers to informed consent; yes(unblinded), no (blinded). If data are solely obtained from archives, students are considered to be blinded. This also covers a potential self-selection bias towards taking part in a study which is eliminated in archive studies.

${ }^{4}$ Total score is constructed from the maximal number of available bias categories within a study type. Green=1 point; orange $=0.5$ points; red=0 points 
medRxiv preprint doi: https://doi.org/10.1101/2021.05.19.21252346; this version posted May 20, 2021. The copyright holder for this preprint (which was not certified by peer review) is the author/funder, who has granted medRxiv a license to display the preprint in perpetuity.

It is made available under a CC-BY-NC-ND 4.0 International license .

\section{Magnitude of effects}

Given that a meta-analysis was not indicated because of the great variation in outcome measures, study designs and analyses, we identified a subgroup of studies that provided standardised beta coefficients to compare the magnitude of grade or score changes across studies and with those of covariates. The statistically significant beta coefficients of the identified 8 studies are plotted in Figure 3a. Overall, the magnitude of the influence of school start times is smaller than SES or ethnical/racial background. In line with this, studies from Edwards ${ }^{55}$ and Bastian and Fuller ${ }^{59}$ demonstrated that it was the disadvantaged and minority students that particularly benefitted from later starts. Importantly, Figure 3a purports a biased picture towards positive results of school start times on achievement given the selection for significant standardised coefficients. Figure $3 \mathrm{~b}$ puts findings from $3 \mathrm{a}$ into perspective with all included studies and paints a very different picture.

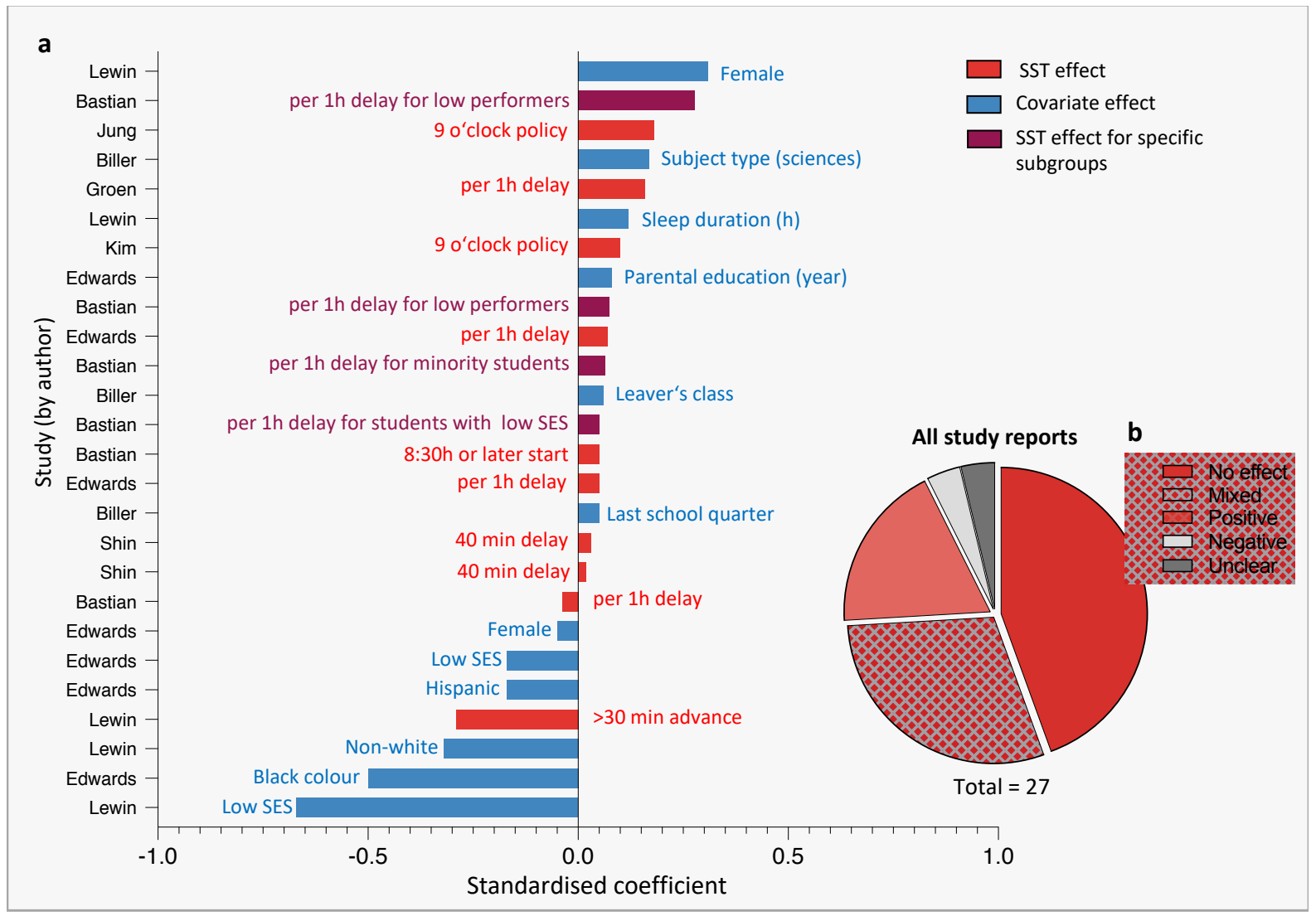

Fig. 3 | Overall study results and effects sizes. a, Standardised beta coefficients ordered by magnitude and study author from the subset of studies that reported standardised coefficients and statistically significant effects ( $n=8$ of 21). Only these statistically significant effects are depicted, non-significant ones were left out. Standardised coefficients are in units of standard deviation of the outcome variable. Quarter refers to the academic quarter of a school year in Germany. Low socioeconomic status was measured as free lunch status. For exact study references see Tab. 1. b, Summary of simplified findings from all included studies $(\mathrm{N}=21)$. The total is $>21$ since several studies reported multiple outcomes. Abbreviations: SST, school start time; SES, socio-economic status. 
medRxiv preprint doi: https://doi.org/10.1101/2021.05.19.21252346; this version posted May 20, 2021. The copyright holder for this preprint

(which was not certified by peer review) is the author/funder, who has granted medRxiv a license to display the preprint in perpetuity.

It is made available under a CC-BY-NC-ND 4.0 International license .

\section{Discussion}

Chronic sleep restriction in teenagers has become a serious health concern worldwide ${ }^{\text {e.g. } 8,70}$. The widespread sleep restriction is largely a result of the conflict between the late sleep times typical of adolescence and the early SSTs imposed by societye.g. 3,71,72. Delaying school start times has the great potential of improving cognitive functioning, physical health and well-being of students mediated by improving sleep (as reviewed elsewher ${ }^{16,25,31}$ ) with possibly relatively little costs ${ }^{73,74}$. But does a delay in SSTs also translate into improved academic achievement in middle and high school students? Our systematic literature search identified 21 studies that investigated whether SSTs have any systematic effect on course grades or (standardised test) scores. The analyses revealed that about half of the studies did not find any effect (neither positive nor negative) of delaying school times on academic performance, while the other half found either mixed or positive results. Just one study found better grades associated with earlier SSTs ${ }^{53}$. Given the high risk of biases observed in most of the studies and the great heterogeneity in school settings, there is a need for more high-quality evidence to draw sound conclusions (see Fig. 4 for suggested improvements).

\section{Methodological considerations}

Our systematic risk of bias assessment showed that the evidence level was mostly moderate (only 5 out of 21 studies achieved a score of $\geq 75 \%$ within their category). Specifically, we did not identify any randomised controlled trials, which is not surprising considering the circumstances of educational research and the hesitation of many schools to participate in such complex and time-consuming study designs ${ }^{75}$. In many studies, basic reporting standards were only partially met, blinding was a high concern in over half of the studies (i.e. high performance bias), and appropriate statistical models which control for confounders were not used in 7 out of 21 studies.

The study design we identified as one of the most commonly used was longitudinal studies with a prepost design that followed a specific cohort of students over time i) including a control group that did not change start times, and ii) without a control group. A second common design was cross-sectional studies that compared different, independent groups of students (either at one specific time point or over several years) with varying start times. Studies that performed best in the risk of bias assessment were mostly longitudinal studies with a control group, a large sample size and with appropriate and advanced statistical analyses that controlled for possible confounders.

\section{Well-designed studies also reveal no clear picture}

What do studies with low risk (i.e., a $\geq 75 \%$ good-evidence-score) conclude about the influence of SSTS on academic achievement? Lenard et al. $(2020)^{56}$ found that advancing SSTs by 40 minutes did not affect ACT scores, while Jung $(2018)^{65}$ showed that delaying start times by $40-60$ min also did not affect grades when personal covariates were controlled for. If studies with a good-evidence-score of $50 \%$ are also considered, the picture is more complex: two studies report small gains in math and reading ${ }^{48,55}$, and one reports small effects on math but not on Korean nor English ${ }^{67}$. Three cross-sectional studies also achieved a good evidence score of over $75 \% \%^{54,58,59}$. The associations found between SSTs and academic achievement again did not point in one direction: Groen and Pabilonia (2019) considered a range of different start times and reported small increases on the Woodcock-Test but only for females and reading ${ }^{58}$, while Hinrichs did not find any positive association of a delay of 85 min on either ACT scores, 
medRxiv preprint doi: https://doi.org/10.1101/2021.05.19.21252346; this version posted May 20, 2021. The copyright holder for this preprint

(which was not certified by peer review) is the author/funder, who has granted medRxiv a license to display the preprint in perpetuity.

It is made available under a CC-BY-NC-ND 4.0 International license .

Kansas assessment scores, or end of course exams ${ }^{54}$. Bastian and Fuller (2018) reported that a 8:30h or later start was necessary for positive associations with $1^{\text {st }}$ period grades ${ }^{59}$. Furthermore, the authors showed that especially lower achievers, minority students and students with a low SES benefit from later starts. In summary, good evidence studies report either no, relatively small, or not generalisable effects of changing SSTs.

\section{Do results for course grades and standardised test scores differ?}

Since course grades and standardised scores possibly measure different underlying skills and knowledge, they might also differ in their sensitivity to SST changes. For instance, standardised test scores seem to be sensitive enough to reflect effects of other school policies, e.g. reducing classroom size $^{76}$ or racial segregation ${ }^{77}$. However, general test scores might be less sensitive to acute changes in SSTs because they measure the accumulated knowledge over several schooling years ${ }^{56}$ and are taken predominantly by high-achieving students, who are prone to ceiling effects. Moreover, they are often scheduled in the morning ${ }^{54}$ and therefore confounded by time-of-day effects on attention and fluid intelligence (e.g. logic, reasoning, problem solving ${ }^{56,78-80}$. Moreover, in the case of ACT or PLAN scores, tests are usually only taken by high-achieving students applying for admission to college - a specific student population which is prone to ceiling effects, making these students less likely to benefit from later SSTs compared to lower-achieving students as two other studies also confirmed ${ }^{55,59}$.

Course grades, on the contrary, derive from exams taken by all students. If collected with high temporal resolution (i.e. more than once per year), they are potentially more sensitive to acute SSTs changes and less influenced by time-of-day effects if distributed evenly across the day. However, grades might be more influenced by certain student characteristics, such as conscientiousness or perseverance ${ }^{81}$. A "teacher bias" could particularly influence the results of interventional studies if not controlled for. Altogether, both standardised test scores and course grades have their pros and cons, which might be the reason why no clear answer emerges even when results are grouped by outcomes: there was no tendency or differential effect on either objective test scores ( 2 positive ${ }^{55,68}, 3$ null findings ${ }^{54,56,57}$, and 4 mixed results ${ }^{58,59,63,67}$ ) or objective grades ( 2 positive ${ }^{48,60}, 4$ null findings $s^{49,57,64,65}$ and 2 mixed results ${ }^{59,61}$ ) or self-reported grades ( 2 positive ${ }^{62,69}, 3$ null findings ${ }^{51,52,66}$, and 1 each for mixed $^{63}$ and negative ${ }^{53}$ ).

\section{Considerations of power and dose}

An alternative explanation for these mixed results could be a lack of statistical power. However, almost all studies had very large sample sizes or number of observations and were able to detect other influences such as gender differences and achievement gaps between whites and non-whites. The effect sizes of these factors tended to be of larger magnitude than effect sizes for changes in school starts (Fig. 3a).

Another interesting consideration is that effects of changed SSTs on achievement might not be linear. When exactly should schools start? How much should schools delay their start times? How long do students need to be exposed to later starts until effects become visible? These are important practical questions that are, however, difficult to answer. Intuitively, one would expect that small delays are not enough to produce robust effects. However, it is not clear whether further delays would be beneficial or even harmful. Hinrichs ${ }^{54}$ tried to model this hypothesis using spline regressions but found no clear answer. Furthermore, the latest start time in the studies reviewed here was 10:00h and the largest delay 
medRxiv preprint doi: https://doi.org/10.1101/2021.05.19.21252346; this version posted May 20, 2021. The copyright holder for this preprint

(which was not certified by peer review) is the author/funder, who has granted medRxiv a license to display the preprint in perpetuity.

It is made available under a CC-BY-NC-ND 4.0 International license .

was 135 min (Fig. 2e). Despite a great variation in delays and SSTs, we were not able to detect any clear dose response curve, i.e. positive effects only appearing with the largest delay. Further studies should clarify this question. Nevertheless, the American Association of Pediatrics recommends to start schools not earlier than 8:30h ${ }^{82}$, which is supported by Bastian and Fuller ${ }^{59}$ who found that only when school started at 8:30h or later, significant positive effects were detected on $1^{\text {st }}$ period grades, although overall grades were unaffected.

A second consideration about dose is how long the school has already operated in a delayed system the longer the delay has been in place, the longer students were exposed. Several studies analysed time trends for several years before and after a change but no unifying results emerge from these studies.

\section{Factors influencing academic achievement}

A very likely reason for inconclusive results derives from the many variables affecting course grades and test scores. Whether these variables are assessed, considered, and controlled for can drastically change the conclusions of a study. These influences range from student-level factors (e.g. chronotype ${ }^{83}$, ethnic or racial background ${ }^{59}$, conscientiousness ${ }^{81}$ or prior knowledge ${ }^{84}$ ) to family-level factors (e.g. parental involvement ${ }^{85}$, parental education ${ }^{65}$, or $\left.\mathrm{SES}^{86}\right)$, and to classroom- and school-level factors (e.g. classroom size ${ }^{76}$ and atmosphere ${ }^{84}$, teacher quality ${ }^{87}$ ). Indeed, we also observed here that SES and race/ethnicity influence achievement (Fig. 3a). Moreover, there are sleep variables, such as sleep duration and daytime sleepiness that play an important role for health, cognition and learning and are often connected to demographic variables, such that students with difficult social backgrounds are also prone to reduced and poorer sleep than their more advantaged peers ${ }^{88,89}$. It is therefore likely that SST delays potentially only translate into meaningful grade or test score benefits in a specific subset of students. Stratified analyses could answer this question but have rarely been done (for notable exceptions see ${ }^{55,59}$ which confirm such tendencies). In general, reflecting on confounders, their influence on academic achievement and on how they might also be affected by changes in SSTs is important for designing future studies.

\section{Limitations of the review}

Although an extensive search across different databases was carried out, an incomplete retrieval of all published articles on the topic cannot be excluded. A total of 21 studies were included, which is far more than in previous reviews (2-12 included studies). We also chose to report grey literature to reduce a possible publication bias in favour of positive results. Previous reviews ${ }^{16}$ decided otherwise to ensure a good quality of the findings reported. However, the included risk of bias assessment allowed for critical reporting of both peer and non-peer-reviewed articles. Since the studied population was restricted to middle and high school students, several studies which used valuable randomisation at the class-level had to be excluded because they included college students (for a review see ${ }^{24}$ ). However, life-style and sleep characteristics widely differ between high school and college students, which is why we focused only on adolescents. We included middle schools, since sleep changes tend to start with the onset of puberty ${ }^{90,91}$ 
medRxiv preprint doi: https://doi.org/10.1101/2021.05.19.21252346; this version posted May 20, 2021. The copyright holder for this preprint (which was not certified by peer review) is the author/funder, who has granted medRxiv a license to display the preprint in perpetuity. It is made available under a CC-BY-NC-ND 4.0 International license .

\section{Final Conclusions}

Our systematic research and analysis of the literature shows that the current evidence does not allow to draw sound conclusions as to whether delaying SSTs improves or is associated with increased achievement at the grade and test score level across all students. This is mostly due to the heterogeneity in school settings and the vast differences between studies with regards to study design, quality and chosen outcome measure and consequently a lack of generalisability of individual study results that also prevented conducting a meta-analysis (see Fig. 4 for suggested improvements). Importantly, as much as course grades and test scores do not systematically or greatly improve across the majority of studies, all included studies (except for one) showed no worsening after a SST delay. This means that SSTs could be delayed, while academic achievement is maintained at the same level (or improved in sub-groups or individuals) and possibly achieved with less cognitive effort or time spent on studying and homework (students are likely better rested and therefore cognitively more capable and efficient). In combination with other reported positive outcomes on sleep, daytime sleepiness, mood and motivation, computer

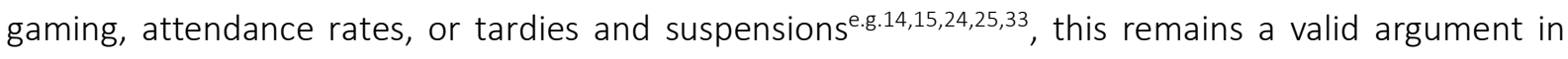
favour of delaying SSTs.

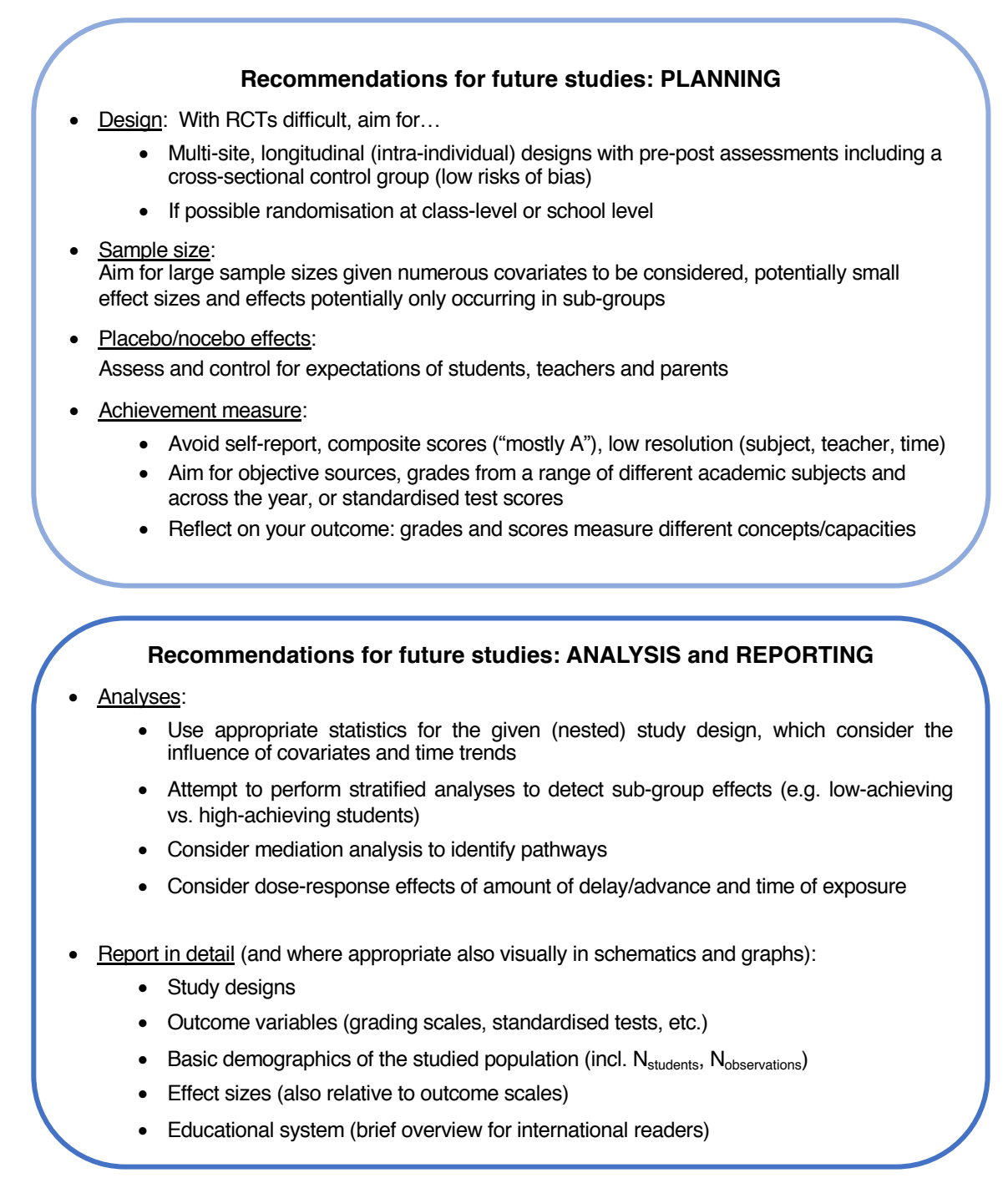

Fig. 4 | Suggestions for future studies. 
medRxiv preprint doi: https://doi.org/10.1101/2021.05.19.21252346; this version posted May 20, 2021. The copyright holder for this preprint (which was not certified by peer review) is the author/funder, who has granted medRxiv a license to display the preprint in perpetuity.

It is made available under a CC-BY-NC-ND 4.0 International license .

\section{Acknowledgements}

We thank all contacted authors who replied and helped us to report their findings as accurately as possible. AMB thanks the Graduate School for Systemic Neurosciences, Munich, for financial support.

\section{Author contributions (CRedIT Taxonomy)}

Conceptualisation: AMB, GZ, ECW

Methodology: AMB, GZ, ECW, KM

Investigation: $\mathrm{AMB}, \mathrm{GZ}$

Data curation: $A M B, G Z$

Formal analysis: $\mathrm{AMB}, \mathrm{GZ}$

Validation: ECW, KM

Supervision: ECW

Visualization: AMB, GZ

Writing - original draft: $A M B, G Z$

Writing - review and editing: AMB, GZ, ECW, KM

\section{Conflict of interest}

AMB received research and travel funds from the Graduate School of Systemic Neurosciences Munich. GZ and KM report no funding in relation to the study and outside the submitted work. ECW reports receiving funds from the German Research Foundation (DFG) during the conduit of this study but outside of the submitted work. 
medRxiv preprint doi: https://doi.org/10.1101/2021.05.19.21252346; this version posted May 20, 2021. The copyright holder for this preprint (which was not certified by peer review) is the author/funder, who has granted medRxiv a license to display the preprint in perpetuity.

It is made available under a CC-BY-NC-ND 4.0 International license.

\section{References}

1. Crowley, S. J. et al. A longitudinal assessment of sleep timing, circadian phase, and phase angle of entrainment across human adolescence. PLoS One 9, (2014).

2. Crowley, S. J., Acebo, C. \& Carskadon, M. A. Sleep, circadian rhythms, and delayed phase in adolescence. Sleep Med. 8, 602-612 (2007).

3. Crowley, S. J., Wolfson, A. R., Tarokh, L. \& Carskadon, M. A. An Update on Adolescent Sleep: New Evidence Informing the Perfect Storm Model. J Adolesc. 55-65 (2018). doi:10.1016/j.adolescence.2018.06.001

4. Carskadon, M. A., Acebo, C. \& Jenni, O. G. Regulation of adolescent sleep: Implications for behavior. Ann. N. Y. Acad. Sci. 1021, 276-291 (2004).

5. Gibson, E. S. et al. 'Sleepiness' is serious in adolescence: Two surveys of 3235 Canadian students. BMC Public Health 6, 116 (2006).

6. Matricciani, L., Olds, T. \& Petkov, J. In search of lost sleep: Secular trends in the sleep time of school-aged children and adolescents. Sleep Medicine Reviews (2012). doi:10.1016/j.smrv.2011.03.005

7. Keyes, K. M., Maslowsky, J., Hamilton, A. \& Schulenberg, J. The Great Sleep Recession: Changes in Sleep Duration Among US Adolescents, 1991-2012. Pediatrics 135, 460-468 (2015).

8. Gradisar, M., Gardner, G. \& Dohnt, H. Recent worldwide sleep patterns and problems during adolescence: A review and meta-analysis of age, region, and sleep. Sleep Medicine (2011). doi:10.1016/j.sleep.2010.11.008

9. Raniti, M. B. et al. Sleep Duration and Sleep Quality: Associations With Depressive Symptoms Across Adolescence. Behav. Sleep Med. (2017). doi:10.1080/15402002.2015.1120198

10. Baum, K. T. et al. Sleep restriction worsens mood and emotion regulation in adolescents. J. Child Psychol. Psychiatry Allied Discip. 55, (2014).

11. Short, M. A., Gradisar, M., Lack, L. C. \& Wright, H. R. The impact of sleep on adolescent depressed mood, alertness and academic performance. J. Adolesc. 36, 1025-1033 (2013).

12. Garaulet, M. et al. Short sleep duration is associated with increased obesity markers in European adolescents: Effect of physical activity and dietary habits. The HELENA study. Int. J. Obes. 35, 1308-1317 (2011).

13. Mullington, J. M., Haack, M., Toth, M., Serrador, J. M. \& Meier-Ewert, H. K. Cardiovascular, inflammatory, and metabolic consequences of sleep deprivation. Prog. Cardiovasc. Dis. 51, 294302 (2009).

14. Bowers, J. M. \& Moyer, A. Effects of school start time on students' sleep duration, daytime sleepiness, and attendance: a meta-analysis. Sleep Heal. 3, 423-431 (2017).

15. Marx, R. et al. Later school start times for supporting the education, health, and well-being of high school students. Cochrane Database Syst. Rev. 2017, (2017).

16. Minges, K. E. \& Redeker, N. S. Delayed school start times and adolescent sleep: A systematic review of the experimental evidence. Sleep Med. Rev. 28, 82-91 (2016).

17. Beebe, D. W., Rose, D. \& Amin, R. Attention, learning, and arousal of experimentally sleeprestricted adolescents in a simulated classroom. J. Adolesc. Heal. (2010). doi:10.1016/j.jadohealth.2010.03.005

18. Killgore, W. D. S. et al. Sleep deprivation reduces perceived emotional intelligence and 
medRxiv preprint doi: https://doi.org/10.1101/2021.05.19.21252346; this version posted May 20, 2021. The copyright holder for this preprint (which was not certified by peer review) is the author/funder, who has granted medRxiv a license to display the preprint in perpetuity. It is made available under a CC-BY-NC-ND 4.0 International license .

constructive thinking skills. Sleep Med. 9, 517-526 (2008).

19. Hysing, M., Haugland, S., Bøe, T., Stormark, K. M. \& Sivertsen, B. Sleep and school attendance in adolescence: Results from a large population-based study. Scand. J. Public Health (2015). doi:10.1177/1403494814556647

20. Walker, M. P. \& Stickgold, R. Sleep, memory, and plasticity. Annu. Rev. Psychol. 57, 139-166 (2006).

21. Stickgold, R. Sleep-dependent memory consolidation. Nature 437, 1272-1278 (2005).

22. Maquet, P. The role of sleep in learning and memory. Science (80-. ). 294, 1048-1052 (2001).

23. Alhola, P. \& Polo-Kantola, P. Sleep deprivation: Impact on cognitive performance. Neuropsychiatric Disease and Treatment 3, 553-567 (2007).

24. Fuller, S. C. \& Bastian, K. C. The Relationship Between School Start Times and Educational Outcomes. Curr. Sleep Med. Reports 18-19 (2020). doi:10.1007/s40675-020-00198-4

25. Wheaton, A. G., Chapman, D. P., Croft, J. B., Chief, B. \& Branch, S. School start times, sleep, behavioral, health and academic outcomes: a review of literature. J Sch Heal. 86, 363-381 (2017).

26. Hofer, M., Kuhnle, C., Kilian, B. \& Fries, S. Cognitive ability and personality variables as predictors of school grades and test scores in adolescents. Learning and Instruction 22, 368-4752 (2012).

27. Fehrmann, P. G., Keith, T. Z. \& Reimers, T. M. Home influence on school learning: Direct and indirect effects of parental involvement on high school grades. J. Educ. Res. 80, 330-671 (1987).

28. Keith, T. Z. \& Benson, M. J. Effects of manipulable influences on high school grades across five ethnic groups. J. Educ. Res. 86, 85-671 (1992).

29. Lekholm, A. K. \& Cliffordson, C. Discrepancies between school grades and test scores at individual and school level: effects of gender and family background. Educ. Res. Eval. 14, 181-3611 (2008).

30. Caprara, G. V., Barbaranelli, C., Steca, P. \& Malone, P. S. Teachers' self-efficacy beliefs as determinants of job satisfaction and students' academic achievement: A study at the school level. J. Sch. Psychol. 44, 473-490 (2006).

31. Alfonsi, V. et al. Later school start time: The impact of sleep on academic performance and health in the adolescent population. Int. J. Environ. Res. Public Health 17, (2020).

32. Berger, A. T., Widome, R. \& Troxel, W. M. Delayed school start times and adolescent health. Sleep and Health (Elsevier Inc., 2019). doi:10.1016/B978-0-12-815373-4.00033-2

33. Hershner, S. Sleep and academic performance: measuring the impact of sleep. Curr. Opin. Behav. Sci. 33, 51-56 (2020).

34. Morgenthaler, T. I. et al. High school start times and the impact on high school students: What we know, and what we hope to learn. J. Clin. Sleep Med. 12, 1681-1689 (2016).

35. Wahlstrom, K. L. \& Owens, J. A. School start time effects on adolescent learning and academic performance, emotional health and behaviour. Curr. Opin. Psychiatry 30, 485-490 (2017).

36. Wolfson, A. R. \& Ziporyn, T. Adolescent sleep and later school start times. in Sleep, Health, and Society: From Aetiology to Public Health 215-223 (2018). doi:10.1093/oso/9780198778240.003.0024

37. Gomez Fonseca, A. \& Genzel, L. Sleep and academic performance: considering amount, quality and timing. Curr. Opin. Behav. Sci. 33, 65-71 (2020). 
medRxiv preprint doi: https://doi.org/10.1101/2021.05.19.21252346; this version posted May 20, 2021. The copyright holder for this preprint

(which was not certified by peer review) is the author/funder, who has granted medRxiv a license to display the preprint in perpetuity.

It is made available under a CC-BY-NC-ND 4.0 International license .

38. Wolfson, A. R. \& Carskadon, M. A. Understanding adolescents' sleep patterns and school performance: a critical appraisal. Sleep Med. Rev. 7, 491-506 (2003).

39. Schmidt, S. Later school starts linked to better teen grades. (2019). Available at: https://www.sciencenewsforstudents.org/article/later-school-starts-linked-better-teen-grades. (Accessed: 21st December 2020)

40. Urton, J. Teens get more sleep, show improved grades and attendance with later school start time, researchers find. (2018). Available at: https://www.washington.edu/news/2018/12/12/high-school-start-times-study/\#: :text=12 in the journal Science, minutes of sleep each night. (Accessed: 21st December 2020)

41. Lee, K. More Evidence Finds That Delaying School Start Times Improves Students' Performance, Attendance, and Sleep. (2018). Available at: https://www.everydayhealth.com/kidshealth/delaying-school-start-times-improves-students-performance-health/. (Accessed: 21st December 2020)

42. Ackerman, X. et al. School Start Times. (2019). Available at: https://ccb.ucsd.edu/_files/bioclock/Infographic PDF, School Start Times 2019, Ackerman, Phan, Gee, Kim, Imani, Welkie, Golden.pdf. (Accessed: 21st December 2020)

43. French, M. T., Homer, J. F., Popovici, I. \& Robins, P. K. What you do in high school matters: High School GPA, educational attainment, and labor market earnings as a young adult. East. Econ. J. 41, 370-386 (2015).

44. Geiser, S. \& Santelices, M. V. Validity of high-school grades in predicting student success beyond the freshman year: High school record vs. standardized tests as indicators of four-year college outcomes. CSHE Res. Occas. Pap. Ser. 35 (2007).

45. Ma, J., Pender, M. \& Welch, M. Education Pays 2016. Coll. Board Trends High. Educ. Ser. 1-44 (2016).

46. Guyatt, G. H. et al. GRADE guidelines: 4. Rating the quality of evidence - Study limitations (risk of bias). J. Clin. Epidemiol. 64, 407-415 (2011).

47. Sterne, J. A. et al. ROBINS-I: a tool for assessing risk of bias in non-randomised studies of interventions. BMJ 355, i4919 (2016).

48. Shin, J. Sleep More, Study Less ? The Impact of Delayed School Start Time on Sleep and Academic Performance. (2018). Available at: https://aefpweb.org/sites/default/files/JShin_Poster_AEFP2020.pdf.

49. Biller, A. M. et al. One year later: longitudinal effects of flexible school start times on teenage sleep, psychological benefits, and academic grades. (2021). Available at: https://syncandshare.Irz.de/public?folderID=MkFWcEdlcUtwU05QNGIxeHNENEU5.

50. Moher, D., Liberati, A., Tetzlaff, J. \& Altman, D. Preferred Reporting Items for Systematic Reviews and MetaAnalyses: The PRISMA Statement. PLoS Med. 6, e1000097 (2009).

51. Boergers, J., Gable, C. J. \& Owens, J. A. Later school start time is associated with improved sleep and daytime functioning in adolescents. J. Dev. Behav. Pediatr. 35, 11-17 (2014).

52. Owens, J. A., Belon, K. \& Moss, P. Impact of delaying school start time on adolescent sleep, mood, and behavior. Arch Pediatr Adolesc Med 164, 608-614 (2010).

53. Milić, J. et al. Are there differences in students' school success, biorhythm, and daytime sleepiness depending on their school starting times? Coll. Antropol. 38, 889-894 (2014).

54. Hinrichs, P. When the bell Tolls: The effects of school starting times on academic achievement. 
medRxiv preprint doi: https://doi.org/10.1101/2021.05.19.21252346; this version posted May 20, 2021. The copyright holder for this preprint (which was not certified by peer review) is the author/funder, who has granted medRxiv a license to display the preprint in perpetuity.

Educ. Financ. Policy 6, 486-507 (2011).

55. Edwards, F. Early to rise? The effect of daily start times on academic performance. Econ. Educ. Rev. 31, 970-983 (2012).

56. Lenard, M., Morrill, M. S. \& Westall, J. High school start times and student achievement: Looking beyond test scores. Econ. Educ. Rev. 76, (2020).

57. Thacher, P. V \& Onyper, S. V. Longitudinal Outcomes of start time delay on sleep, behavior, and achievement in high school. Sleep 39, 271-281 (2016).

58. Groen, J. A. \& Pabilonia, S. W. Snooze or lose: High school start times and academic achievement. Econ. Educ. Rev. 72, 204-218 (2019).

59. Bastian, K. C. \& Fuller, S. C. Answering the Bell: High School Start Times and Student Academic Outcomes. AERA Open 4, 233285841881242 (2018).

60. Dunster, G. P. et al. Sleepmore in Seattle: Later school start times are associated with more sleep and better performance in high school students. Sci Adv 4, eaau6200 (2018).

61. Wolfson, A. R., Spaulding, N. L., Dandrow, C. \& Baroni, E. M. Middle school start times: The importance of a good night's sleep for young adolescents. Behav. Sleep Med. 5, 194-209 (2007).

62. Wahlstrom, K. L., Frederickson, J. \& Wrobel, G. School Start Time Study: Technical Report, Volume II Analysis of Student Survey Data. (1997).

63. Wahlstrom, K. L. et al. Examining the Impact of Later High School Start Times on the Health and Academic Performance of High School Students: A Multi-Site Study. (2014).

64. Wahlstrom, K. Changing Times: Findings From the First Longitudinal Study of Later High School Start Times. NASSP Bull. 86, 3-21 (2002).

65. Jung, H. A late bird or a good bird? The effect of 9 o'clock attendance policy on student's achievement. Asia Pacific Educ. Rev. 19, 511-529 (2018).

66. Rhie, S. \& Chae, K. Y. Effects of school time on sleep duration and sleepiness in adolescents. PLoS One 13, e0203318 (2018).

67. Kim, T. The Effects of School Start Time on Educational Outcomes: Evidence From the 9 O'Clock Attendance Policy in South Korea. SSRN Electron. J. 1-26 (2018). doi:10.2139/ssrn.3160037

68. Kelley, P., Lockley, S. W., Kelley, J. \& Evans, M. D. R. R. Is 8:30 a.m. still too early to start school? A 10:00 a.m. school start time improves health and performance of students aged 13-16. Front. Hum. Neurosci. 11, (2017).

69. Lewin, D. S. et al. Variable School Start Times and Middle School Student's Sleep Health and Academic Performance. J. Adolesc. Heal. 61, 205-211 (2017).

70. Chattu, V. et al. The Global Problem of Insufficient Sleep and Its Serious Public Health Implications. Healthcare 7, 1 (2018).

71. Carskadon, M. A. Factors influencing sleep patterns of adolescents. in Adolescent Sleep Patterns: Biological, Social, and Psychological Influences. (Cambridge University Press, 2002).

72. Wittmann, M., Dinich, J., Merrow, M. \& Roenneberg, T. Social Jetlag: Misalignment of Biological and Social Time. Chronobiol. Int. 23, 497-509 (2006).

73. Hafner, M., Stepanek, M. \& Troxel, W. M. The economic implications of later school start times in the United States. Sleep Heal. 3, 451-457 (2017).

74. Jacob, B. A. \& Rockoff, J. E. Organizing schools to improve student achievement: Start times, 
medRxiv preprint doi: https://doi.org/10.1101/2021.05.19.21252346; this version posted May 20, 2021. The copyright holder for this preprint (which was not certified by peer review) is the author/funder, who has granted medRxiv a license to display the preprint in perpetuity.

It is made available under a CC-BY-NC-ND 4.0 International license .

grade configurations, and teacher assignments. Hamilt. Proj. 24 (2011).

75. Illingworth, G. et al. Challenges in implementing and assessing outcomes of school start time change in the UK: experience of the Oxford Teensleep study. Sleep Med. 60, 89-95 (2019).

76. Krueger, A. B. \& Whitmore, D. M. The effect of attending a small class in the early grades on college-test taking and middle school test results: Evidence from Project STAR. Econ. J. 111, 128 (2001).

77. Card, D. \& Rothstein, J. Racial segregation and the black-white test score gap. J. Public Econ. 91, 2158-2184 (2007).

78. Hansen, M., Janssen, I., Schiff, A., Zee, P. C. \& Dubocovich, M. L. The impact of school daily schedule on adolescent sleep. Pediatrics 115, 1555-1561 (2005).

79. Fimm, B., Brand, T. \& Spijkers, W. Time-of-day variation of visuo-spatial attention. Br. J. Psychol. 107, 299-321 (2016).

80. Zerbini, G. et al. Lower school performance in late chronotypes: underlying factors and mechanisms. Sci Rep 7, 4385 (2017).

81. Rimfeld, K., Kovas, Y., Dale, P. S. \& Plomin, R. True grit and genetics: Predicting academic achievement from personality. J. Pers. Soc. Psychol. 111, 780-789 (2016).

82. American Academy of Pediatrics. School Start Times for Adolescents. Pediatrics 134, 642-649 (2014).

83. Zerbini, G. \& Merrow, M. Time to learn: How chronotype impacts education. Psych J 6, 263-276 (2017).

84. Neumann, K., Kauertz, A. \& Fischer, H. E. Quality of instruction in science education. in Second international handbook of science education (eds. Fraser, B. J., Tobin, K. G. \& McRobbie, C. J.) 247-258 (Berlin: Springer, 2012). doi:10.1007/978-1-4020-9041-7

85. Juang, L. P. \& Silbereisen, R. K. The relationship between adolescent academic capability beliefs, parenting and school grades. J. Adolesc. 25, 3-18 (2002).

86. Pokropek, A., Borgonovi, F. \& Jakubowski, M. Socio-economic disparities in academic achievement: A comparative analysis of mechanisms and pathways. Learn. Individ. Differ. 42, 1018 (2015).

87. Rockoff, J. E. The impact of individual teachers on student achievement: Evidence from panel data. Am. Econ. Rev. 94, 247-252 (2004).

88. Jarrin, D. C., McGrath, J. J. \& Quon, E. C. Objective and subjective socioeconomic gradients exist for sleep in children and adolescents. Health Psychol. 33, 301-305 (2014).

89. El-Sheikh, M., Kelly, R. J., Buckhalt, J. A. \& Benjamin Hinnant, J. Children's sleep and adjustment over time: The role of socioeconomic context. Child Dev. 81, 870-883 (2010).

90. Dahl, R. E., Allen, N. B., Wilbrecht, L. \& Suleiman, A. B. Importance of investing in adolescence from a developmental science perspective. Nature 554, 441-450 (2018).

91. Roenneberg, T. et al. A marker for the end of adolescence. Curr. Biol. 14, 1038-1039 (2004). 
Tab. 2 | Detailed descriptions of included studies. Studies are ordered by their type of study design (longitudinal with control group, without control group and cross-sectional). Study designs of two studies could not clearly be clearly defined. Abbreviations: SST, school start time; OLS, ordinary least square; SD, standard deviation; b, unstandardised beta coefficient; $\beta$, standardised beta coefficient; $\mu$, average; CG, control group; IG, intervention group; CSAT, College Scholastic Ability Test; GPA, grade point average; ACT, American College Test; OR, odds ratio; NA, not available.

\begin{tabular}{|c|c|c|c|c|c|c|}
\hline $\begin{array}{l}\text { Author(s) } \\
\text { (Year) }\end{array}$ & Study Design & Sample characteristics & $\begin{array}{c}\text { Measure of } \\
\text { school achievement }\end{array}$ & Type of analysis & $\begin{array}{c}\text { Change in SSTs } \\
\text { results in }\end{array}$ & Key findings \\
\hline \multicolumn{7}{|c|}{ LONGITUDINAL (within-subjects comparison) with control group } \\
\hline $\begin{array}{l}\text { Edwards } \\
\text { et al. } \\
(2012) \\
55\end{array}$ & $\begin{array}{l}\text { Schools: } 22-28 \text { or } 15-17 \text { middle } \\
\text { schools? } \\
9 \text { schools delayed, } 4 \text { advanced, } 11 \\
\text { did not change } \\
\text { SST Change: } \\
\text { pre-change: } 07: 30 \text { - 08:45 } \\
\text { post-change: 7:30-8:25 } \\
\text { Assessment: } 1999-2006 \\
\text { Exposure time: NA } \\
\text { Sampling resolution: once per year }\end{array}$ & 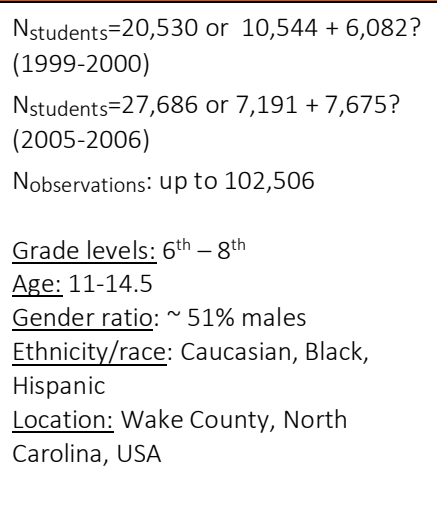 & $\begin{array}{l}\text { Outcome: End of year } \\
\text { standardised test scores in } \\
\text { reading and math } \\
\text { Scale: } 0 \%-100 \% \text { (inferred); } \\
\text { converted to percentile scores for } \\
\text { each student within their grade } \\
\text { and current year } \\
\text { Provided by: Wake Country } \\
\text { administration }\end{array}$ & $\begin{array}{l}\text { Pooled OLS models, } \\
\text { quantile regression } \\
\text { model predicting scores } \\
\text { Covariates: several on } \\
\text { student-level and school- } \\
\text { level } \\
\text { Fixed-effects: student } \\
\text { and school }\end{array}$ & $\begin{array}{l}\text { Per } 1 \mathrm{~h} \text { delay in SST: } \\
1.8-2.9 \text { percent points }(0.06-0.07 \mathrm{SD}) \\
\text { increase in maths and } 1.0-3.4 \text { percent } \\
\text { points }(0.04-0.05 \text { SD) increase in reading } \\
\text { when using within schools variation or } \\
\text { both within and between school variation } \\
\text { (both } p<0.01) \\
\text { Some covariate results for maths and } \\
\text { school fixed effect: } \\
\text { Black colour: } \beta=-0.50(p<0.01) \\
\text { Hispanic: } \beta=-0.17(p<0.01) \\
\text { Female: } \beta=-0.054(p<0.01) \\
\text { Free lunch status: } \beta=-0.17(p<0.01) \\
\text { Parent education (years): } \beta=0.08(p<0.01)\end{array}$ & $\begin{array}{l}\text { Up to } 0.07 \text { SD gains in } \\
\text { maths and } 0.05 \text { SD } \\
\text { increase in reading } \\
\text { end-of-year } \\
\text { standardised scores } \\
\text { even when adjusted } \\
\text { for covariates } \\
\text { The effect was } \\
\text { stronger for lower } \\
\text { achieving students }\end{array}$ \\
\hline $\begin{array}{l}\text { Jung } \\
(2018) \\
65\end{array}$ & $\begin{array}{l}\text { Schools: drawn sample from } 85 \\
\text { elementary and } 63 \text { middle schools; } \\
\text { Cohorts from the Gyeonggi } \\
\text { Education Panel Study } \\
\text { SST Change: } \\
\text { pre-change: } 8: 00-8: 20 \\
\text { post-change: } 9: 00 \\
\text { Assessment: 2012-2017; SST delay } \\
\text { in 2014; i.e. data cover } 3 \text { years prior } \\
\text { and } 2 \text { years after the change } \\
\text { Exposure time: } 2 \text { years } \\
\text { Sampling resolution: once per year }\end{array}$ & 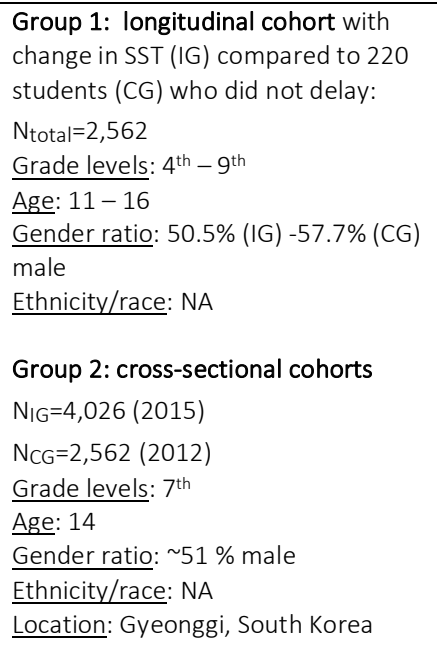 & $\begin{array}{l}\text { Outcome: Korean, English and } \\
\text { math grades at the end of the } \\
\text { spring semester } \\
\text { Scale: NA } \\
\frac{\text { Provided by: governmental }}{\text { agency }}\end{array}$ & $\begin{array}{l}\text { Difference-in-difference } \\
\text { estimation / OLS } \\
\text { estimation } \\
\text { Covariates: various } \\
\text { student-level and school- } \\
\text { level characteristics, } \\
\text { Fixed effects: year, } \\
\text { individual } \\
\text { Cross-sectional } \\
\text { comparison as } \\
\text { robustness check }\end{array}$ & $\begin{array}{l}\text { At first sight, math and English test scores } \\
\text { increased (also Korean but } p>0.05 \text { ); when } \\
\text { controlling for personal covariates the } \\
\text { effect becomes smaller and } n . s \text {. for math; } \\
\text { when applying individual-fixed effect } \\
\text { estimation the result becomes negative } \\
\text { (significantly for Korean) } \\
\text { Model specification } 4 \text { with Year fixed } \\
\text { effects and all personal covariates: } \\
\text { Korean: } \beta=0.048 \text { ( } p>0.05 \text { ) } \\
\text { Math: } \beta=0.16 \text { ( } p>0.05) \\
\text { English: } \beta=0.18 \text { ( } p<0.01) \\
\text { Cross-sectional robustness check confirms } \\
\text { longitudinal results }\end{array}$ & $\begin{array}{l}\text { No effect on Korean, } \\
\text { English or math test } \\
\text { scores when } \\
\text { controlling for } \\
\text { personal covariates or } \\
\text { unobserved individual } \\
\text { heterogeneities } \\
\text { Caveat: Sleep } \\
\text { duration did not } \\
\text { differ between CG } \\
\text { and IG! }\end{array}$ \\
\hline
\end{tabular}




\begin{tabular}{|c|c|c|c|c|c|c|}
\hline $\begin{array}{l}\text { Kim } \\
\text { (2018) } \\
67\end{array}$ & $\begin{array}{l}\text { Schools: high schools from } 2 \\
\text { districts; Gyeonggi delayed (IG) and } \\
\text { Seoul did not delay (CG) } \\
\text { SST Change: } \\
\text { pre-change in IG: varying between } \\
\text { earlier than 7:40 and 9:00 } \\
\text { post-change in IG: 9:00 } \\
\text { SST in CG: varying between earlier } \\
\text { than 8:00 and 9:00 } \\
\text { Assessment: } 2009 \text { to 2016; policy } \\
\text { change to 9:00 starts in Sept,2014 } \\
\text { in Gyeonggi; i.e. data cover } 5 \text { years } \\
\text { prior and } 2 \text { years after the change } \\
\text { Exposure time: } 2 \text { years } \\
\text { Sampling resolution: once per year }\end{array}$ & $\begin{array}{l}\text { Group A: Schools in IG } \\
\text { Group B: Schools in CG } \\
\text { Nobservations= up to } 1,479,131 \\
\text { Grade levels: } 9^{\text {th }}-12^{\text {th }} \\
\text { Age: } 15-18 \\
\text { Gender ratio: } 52 \% \text { males } \\
\text { Ethnicity/race: NA } \\
\text { Location: Gyeonggi and Seoul, South } \\
\text { Korea }\end{array}$ & $\begin{array}{l}\text { Outcomes: } \\
\text { (1) Annual National Assessment } \\
\text { of Educational Achievement } \\
\text { (Korean, math, English) for } 9^{\text {th }} \\
\text { and } 11^{\text {th }} \text { graders } \\
\text { (2) College Scholastic Ability Test } \\
\text { (CSAT) for } 12^{\text {th }} \text { graders } \\
\text { Scale: NA } \\
\text { Provided by: EduDataService } \\
\text { System }\end{array}$ & $\begin{array}{l}\text { Difference-in-differences } \\
\text { method } \\
\text { Covariates: regional time } \\
\text { trends } \\
\text { Fixed effects: individual } \\
\text { and school } \\
\text { Several robustness } \\
\text { checks }\end{array}$ & $\begin{array}{l}\text { Results } 11^{\text {th }} \text { graders: } \\
\text { Math scores especially in male students } \\
\text { increased by } 0.06-0.1 \text { SD ( } p<0.01) \text {. Results } \\
\text { are robust when adding covariates to the } \\
\text { model. Korean and English scores become } \\
\text { non-significant when control variables are } \\
\text { added to the model. } \\
\text { For } 12^{\text {th }} \text { graders: } \\
\text { For CSAT no statistically significant benefit } \\
\text { from the } 9 \text { o'clock-policy }\end{array}$ & $\begin{array}{l}\text { Small effects on } \\
\text { math, but not on } \\
\text { Korean or English } \\
\text { standardised scores } \\
\text { No effect on CSAT } \\
\text { scores (possible time- } \\
\text { of-day interference: } \\
\text { the CSAT is scheduled } \\
\text { before } 9 \text { am) }\end{array}$ \\
\hline $\begin{array}{l}\text { Rhie \& } \\
\text { Chae } \\
\text { (2018) } \\
\text { 66 }\end{array}$ & $\begin{array}{l}\text { Schools: several middle (MS) and } \\
\text { high schools (HS); } \\
\text { Gyeonggi district delayed SST (IG) } \\
3 \text { other districts did not delay (CG) } \\
\text { SST Change: } \\
\text { pre-change (IG): 7:30 - 8:10 } \\
\text { post-change (IG): 9:00 } \\
\text { (MS delayed by 30-60min; } \\
\text { HS delayed by 60-90min) } \\
\text { SST in CG: 7:30 - 8:00 } \\
\text { Assessment: } 2 \text { years of data before } \\
\text { and after the change (2012-2016); } \\
\text { 2014 as the year of change was } \\
\text { excluded } \\
\text { Sampling resolution: once per year } \\
\text { Exposure time: } 2 \text { years }\end{array}$ & $\begin{array}{l}N_{\mathrm{NG}}=42,517 \\
\mathrm{~N}_{\mathrm{CG}}=28,287 \\
\text { Grade levels: } 7^{\text {th }}-11^{\text {th }} \text { or } 12^{\text {th }} \\
\text { Age: NA } \\
\text { Gender ratio: } ~ \\
\text { Ethnicity/race: NA male } \\
\text { Location IG: Gyeonggi district and } \\
\text { Daegu/Gyeongbuk/Ulsan district, } \\
\text { South Korea }\end{array}$ & $\begin{array}{l}\text { Outcome: Self-reported GPAs } \\
\text { Scale: Percentage of students } \\
\text { having" high and moderate GPAs" } \\
\text { Provided by: participants }\end{array}$ & $\begin{array}{l}\text { Logistic regression } \\
\text { analysis using complex } \\
\text { samples } \\
\text { Covariates: NA }\end{array}$ & $\begin{array}{l}\text { Percentage of students reporting "high } \\
\text { and mid high GPAs": } \\
\text { Years 2012, 2013, 2015, 2016: } \\
\text { IG }=34.3 \%, 33.9 \%, 38.4 \% *, 37.8 \% * \\
\text { CG }=39.8 \% *, 36.7 \%, 40.6 \% *, 39.4 \%^{*} \\
\text { *: different from } 2013 \text { on } p<0.05\end{array}$ & $\begin{array}{l}\text { No 9AM policy effect } \\
\text { on self-reported GPAs }\end{array}$ \\
\hline
\end{tabular}




\begin{tabular}{|c|c|c|c|c|c|c|}
\hline $\begin{array}{l}\text { Shin } \\
\text { (2018) } \\
48\end{array}$ & $\begin{array}{l}\text { Schools: all middle schools in } 2 \\
\text { districts ( } 599 \text { schools in Gyeonggi } \\
\text { and } 383 \text { schools in Seoul) } \\
\text { SST Change: } \\
\text { pre-change in Gyeonggi (IG): 8:20 } \\
\text { post-change in Gyeonggi (IG): 9:00 } \\
\text { SST in Seoul (CG): varying between } \\
\text { before 8:00 and 9:00 } \\
\text { Assessment: 2013-2015 with the } \\
\text { policy change to 9:00 starts in Sept } \\
\text { 1,2014 in Gyeonggi } \\
\text { Exposure time: } 1 \text { year } \\
\text { Sampling resolution: once/semester }\end{array}$ & $\begin{array}{l}\text { Nobservations }=\text { up to } 33,282 \\
\text { Grade levels: } 7^{\text {th }}-9^{\text {th }} \\
\text { Age: NA } \\
\text { Gender ratio: } ~ \\
\text { contact with author) } \\
\text { Ethnicity/race: mostly Asian (from } \\
\text { private correspondence with author) } \\
\text { Location: Gyeonggi and Seoul, South } \\
\text { Korea }\end{array}$ & $\begin{array}{l}\text { Outcome: Semester grades } \\
\text { (standardised) for math and } \\
\text { reading } \\
\text { Scale: numeric; 0-100; normalized } \\
\text { by population distribution } \\
\text { Provided by: Korean Education \& } \\
\text { Research Information Service }\end{array}$ & $\begin{array}{l}\text { Difference-in-difference } \\
\text { methods } \\
\text { Covariates: various } \\
\text { individual and school- } \\
\text { level variables } \\
\text { Fixed effects: year, } \\
\text { month }\end{array}$ & $\begin{array}{l}\text { Increase in math }(0.03 \mathrm{SD}) \text { and reading } \\
\text { grades ( } 0.02 \mathrm{SD} \text {; (both } p<0.001)\end{array}$ & $\begin{array}{l}\text { Up to } 0.03 \text { SD } \\
\text { increase in math and } \\
0.02 \text { SD increase in } \\
\text { reading semester } \\
\text { grades when adjusted } \\
\text { for time-trends and } \\
\text { other covariates }\end{array}$ \\
\hline $\begin{array}{l}\text { Lenard } \\
\text { et al. } \\
(2020) \\
56\end{array}$ & $\begin{array}{l}\text { Schools: } 19 \text { high schools, of which } \\
5 \text { schools advanced SST (IG) and } 14 \\
\text { did not (CG) } \\
\text { SST Change: } \\
\text { pre-change (IG): 8:05 } \\
\text { post-change (IG): 7:25 } \\
\text { SST in CG: 7:25 } \\
\text { Assessment: data span 2008-2019 } \\
\text { with SST advance in 2012-2013 } \\
\text { Exposure time: } 7 \text { years } \\
\text { Sampling resolution: once per year }\end{array}$ & $\begin{array}{l}\text { Nstudents } 10,000 \text { per each } 8 \text { cohorts } \\
\text { Nobservations }=\text { up to } 52,854 \text { (ACT } \\
\text { scores) } \\
\text { Grade levels: } 8^{\text {th }}-12^{\text {th }} \text { (inferred) } \\
\text { Age: NA } \\
\text { Gender ratio: } ~ 50 \% \text { males } \\
\text { Ethnicity/race: White, African } \\
\text { American, Hispanic, other } \\
\text { Location: Wake County, North } \\
\text { Carolina, USA }\end{array}$ & $\begin{array}{l}\text { Outcome: ACT scores in } 11^{\text {th }} \\
\text { grade (composite and individual } \\
\text { scores for English, reading, math } \\
\text { and science) } \\
\text { Scale: } 1-36 \text { (= best) } \\
\text { Provided by: Wake County } \\
\text { administration }\end{array}$ & $\begin{array}{l}\text { Difference-in-difference } \\
\text { estimation approach } \\
\text { Comparative interrupted } \\
\text { time series } \\
\text { Covariates: various } \\
\text { individual and school- } \\
\text { level variables }\end{array}$ & $\begin{array}{l}\text { No effect of earlier start times on ACT } \\
\text { composite or individual subject ACT scores } \\
\text { (independent of length of exposure) } \\
\text { ACT composite scores: } \\
\text { Partial exposure: } \beta=0.023, p>0.05 \\
\text { Early start all years: } \beta=-0.167, p>0.05 \\
\text { Treated schools all: } \beta=0.273, p>0.05 \\
\text { Scores were trending in all schools with } \\
\text { math scores dropping over subsequent } \\
\text { cohort groups, while English, reading and } \\
\text { science were rising }\end{array}$ & $\begin{array}{l}\text { No effect on } \\
\text { individual or } \\
\text { composite ACT scores } \\
\text { when start times are } \\
\text { advanced }\end{array}$ \\
\hline $\begin{array}{l}\text { Author(s) } \\
\text { (Year) }\end{array}$ & Study Design & Sample characteristics & $\begin{array}{c}\text { Measure of } \\
\text { school achievement }\end{array}$ & Type of analysis & $\begin{array}{l}\text { Change in SSTs } \\
\text { results in }\end{array}$ & Key findings \\
\hline \multicolumn{7}{|c|}{ LONGITUDINAL (within-subjects comparison) without control group } \\
\hline $\begin{array}{l}\text { Biller } \\
\text { et al. }{ }^{49}\end{array}$ & $\begin{array}{l}\text { School: } 1 \text { high school } \\
\text { SST Change: } \\
\text { pre-change: mostly 8:00 } \\
\text { post-change: 8:00 or 8:50 } \\
\text { (flexible choice on a daily basis) } \\
\text { Assessment: data span } 4 \text { years (2.5 }\end{array}$ & $\begin{array}{l}\text { Nstudents }=63-157 \\
\text { Nobservations }=\text { up to } 16,724 \\
\frac{\text { Grade levels: }}{7^{\text {th }}-12^{\text {th }}} \\
\frac{\text { Gge: } 14-21}{\text { Gender ratio: }}: 30-40 \% \text { males } \\
\frac{\text { Ethnicity/race: }}{\text { Location: }} \text { Alsdorf, Aachen region, } \\
\text { Germany }\end{array}$ & $\begin{array}{l}\text { Outcome: quarterly grades of } 12 \\
\text { academic subjects of } 3 \text { disciplines } \\
\text { (sciences, social sciences, } \\
\text { languages) } \\
\text { Scale: numeric, } 0 \%-100 \% \text { (= best) } \\
\text { Provided by: school registry }\end{array}$ & $\begin{array}{l}\text { Linear mixed models } \\
\text { predicting quarterly } \\
\text { grades } \\
\text { Covariates (in all } \\
\text { models): gender, grade } \\
\text { level, academic } \\
\text { discipline, academic } \\
\text { quarter }\end{array}$ & $\begin{array}{l}\text { No effect of flexible system on grades: } \\
\beta=0.00 \text { ( } p>0.05 \text { ) } \\
\text { No absolute sleep effects on grades } \\
\text { No effects of changes in sleep duration or } \\
\text { chronotype from baseline to the flexible } \\
\text { system on grades except for social jetlag } \\
\text { (post } \beta=0.03, p=0.027 \text { ) }\end{array}$ & $\begin{array}{l}\text { No effect of the } \\
\text { flexible system nor } \\
\text { sleep duration or } \\
\text { chronotype on } \\
\text { quarterly objective } \\
\text { grades when } \\
\text { controlled for } \\
\text { covariates }\end{array}$ \\
\hline
\end{tabular}




\begin{tabular}{|c|c|c|c|c|c|c|}
\hline & $\begin{array}{l}\text { before and } 1.5 \text { years after the } \\
\text { change) } \\
\text { Exposure time: } 0.5-1.5 \text { years } \\
\text { Sampling resolution: } 4 \text { times/year }\end{array}$ & & & $\begin{array}{l}\text { Predictors (in some } \\
\text { models): chronotype } \\
\left(+ \text { change from } t_{0}-t_{1}\right), \\
\text { social jetlag (+change } \\
\left.\text { from to- } t_{1}\right) \text {, } \\
\text { sleep duration (+change } \\
\left.\text { from to- } t_{1}\right) \text {, amount of } \\
\text { 8:50AM-use }\end{array}$ & $\begin{array}{l}\text { Covariates (numbers from models 3a- } d) \text { : } \\
\text { Male: } \beta=0.07(p>0.05) \\
\text { Grade level } 12: \beta=0.06(p<0.001) \\
\text { Quarter } 4: \beta=0.05(p<0.001) \\
\text { Social Sciences: } \beta=0.17(p<0.001)\end{array}$ & \\
\hline $\begin{array}{l}\text { Boergers } \\
\text { et al. } \\
(2014) \\
51\end{array}$ & $\begin{array}{l}\frac{\text { School: } 1 \text { independent high school }}{\text { (boarding school) }} \\
\frac{\text { SST Change: }}{\text { pre-change }\left(\mathrm{t}_{1}\right): 08: 00} \\
\text { post-change }\left(\mathrm{t}_{2}\right): 08: 25 \\
\text { back-change }\left(\mathrm{t}_{3}\right): 08: 00 \\
\text { Assessment: Nov } 2010\left(\mathrm{t}_{1}\right), \text { Mar } \\
\text { Exposure time: }{ }^{2} 5 \text { months (during } \\
\frac{\text { Exinter term) }}{\text { Wampling resolution: once/ time }} \\
\frac{\text { point }}{\text { paint }}\end{array}$ & $\begin{array}{l}N_{\text {students }}=197 \\
\text { Grade levels: } 9^{\text {th }}-12^{\text {th }} \\
\text { Age: } \mu=15.6 \\
\text { Gender ratio: } 41 \% \text { males } \\
\text { Ethnicity/race: White, Black, Hispanic } \\
\text { Asian, multiracial or other } \\
\text { Location: Rhode Island, USA }\end{array}$ & $\begin{array}{l}\text { Outcome: Self-reported grades } \\
\text { Scale: categorical; "mostly Bs or } \\
\text { better" } \\
\text { Provided by: students }\end{array}$ & $\begin{array}{l}\text { No type of analyses } \\
\text { stated } \\
\text { Covariates: NA }\end{array}$ & $\begin{array}{l}\text { After the delay in SST, the percentage of } \\
\text { self-reported "mostly Bs or better" } \\
\text { changed from } 93 \%\left(\mathrm{t}_{1}\right) \text { to } 91 \%\left(\mathrm{t}_{2}\right)\end{array}$ & $\begin{array}{l}\text { Unclear as statistics } \\
\text { are not reported; } \\
\text { authors report no } \\
\text { effect }\end{array}$ \\
\hline $\begin{array}{l}\text { Owens } \\
\text { et al. } \\
(2010) \\
52\end{array}$ & $\begin{array}{l}\text { School: } 1 \text { independent high school } \\
\text { (boarding and day school) } \\
\text { SST Change: } \\
\text { pre-change: } 8: 00 \\
\text { post-change: 8:30 } \\
\text { Assessment: Dec 2008, Mar } 2009 \\
\text { Exposure time: } 2 \text { months (January- } \\
\text { March 2009) } \\
\text { Sampling resolution: once/time } \\
\text { point }\end{array}$ & $\begin{array}{l}\text { Nstudents }=201 \\
\text { Grade levels: } 9^{\text {th }}-12^{\text {th }} \\
\text { Age: } \mu^{\sim 16.5} \\
\text { Gender ratio: } ~ 43 \% \text { males } \\
\text { Ethnicity/race: NA } \\
\text { Location: Rhode Island, USA }\end{array}$ & $\begin{array}{l}\text { Outcome: Self-reported grades } \\
\text { Scale: categorical; "mostly B's or } \\
\text { better" } \\
\text { Provided by: participants }\end{array}$ & $\begin{array}{l}\chi^{2} \text { analysis } \\
\text { Covariates: NA }\end{array}$ & $\begin{array}{l}\text { After the delay in SST, the percentage of } \\
\text { self-reported "mostly B's or better" } \\
\text { changed from } 82.2 \% \text { to } 87.1 \% \\
\mathrm{OR}=0.70 \text {; } \\
95 \% \mathrm{Cl}=0.41-1.20, \mathrm{X}^{2}=1.71, \mathrm{p}=0.22\end{array}$ & $\begin{array}{l}\text { No effect on self- } \\
\text { reported grades }\end{array}$ \\
\hline $\begin{array}{l}\text { Thacher } \\
\text { \& Onyper } \\
\text { (2016) } \\
57\end{array}$ & $\begin{array}{l}\text { School: } 1 \text { public high school } \\
\text { SST Change: } \\
\text { pre-change: } 7: 45 \\
\text { post-change: } 8: 30 \\
\text { Assessment: data span 2010-2014; } \\
\text { years of data before and after the } \\
\text { change in 2012 } \\
\text { Exposure time: } 1 \text {-2 years }\end{array}$ & $\begin{array}{l}N_{\text {students }} \sim 650-800 \text { across } 4 \text { years } \\
\text { (but t-test for cross-sectional } \\
\text { comparisons seems to be } \sim 250-330 \text { ) } \\
\text { Grade levels: } 9^{\text {th }}-12^{\text {th }} \\
\text { Age: } \mu^{\sim 16.5} \\
\text { Gender ratio: NA } \\
\text { Ethnicity/race: NA } \\
\text { Location: Glen Falls, NY, USA }\end{array}$ & $\begin{array}{l}\text { Outcomes: } \\
\text { (1) Weighted average GPAs and } \\
\text { subject-specific GPAs (English, } \\
\text { science, math, social studies, art, } \\
\text { music, foreign language, and } \\
\text { health studies) } \\
\text { (2) Standardised test scores from } \\
\text { Regents Exams for cross-sectional } \\
\text { comparison }\end{array}$ & $\begin{array}{l}\text { Longitudinal } \\
\text { comparisons: } \\
\text { mixed effect analyses } \\
\text { including within-subject } \\
\text { effect control }\end{array}$ & $\begin{array}{l}\text { Longitudinal comparison: } \\
\text { no statistically significant evidence for } \\
\text { improvement/decline in GPA } \\
\text { (overall and by subject) } \\
\text { Effect of grade level (higher grade levels } \\
\text { better grade), gender (males worse; } \\
p=0.011-0.059 \text { ), free lunch status } \\
\text { ( } p<0.001 \text { ) independent of SST } \\
\text { No exact numbers are reported }\end{array}$ & $\begin{array}{l}\text { No (systematic) effect } \\
\text { on overall GPAs in } \\
\text { longitudinal } \\
\text { comparison }\end{array}$ \\
\hline
\end{tabular}




\begin{tabular}{|c|c|c|c|c|c|c|}
\hline & Sampling resolution: once/year & & $\begin{array}{l}\text { Scale: numeric; } 100 \text { point scale } \\
\text { for GPAs } \\
\text { Scale for Regents Exam: NA } \\
\text { Provided by: school }\end{array}$ & $\begin{array}{l}\text { Cross-sectional } \\
\text { comparisons: } \\
\text { independent-samples t- } \\
\text { tests for grades and } \\
\text { standardised test scores }\end{array}$ & $\begin{array}{l}\text { Cross-sectional by grade level: } \\
\text { (1) GPA: } \\
\text { Only } 11^{\text {th }} \text { graders' GPAs increased by } 2.55 \\
\text { percent points after the change: } \\
\text { Mean before: } 78.79 \% \text { (SD } 11.11) \\
\text { Mean after: } 81.34 \& \text { (SD } 8.79) \\
\text { t295 }=2.20, p=0.028 \\
\text { (2) Regents exams: } \\
2 \text { of } 20 \text { subject test } s c o r e s \text { ( } 10^{\text {th }} \text { grade } \\
\text { Earth Sciences and } 11^{\text {th }} \text { grade Algebra) } \\
\text { were significant better before the change } \\
\text { ( }<<0.007)\end{array}$ & $\begin{array}{l}\text { GPA test scores of } \\
11^{\text {th }} \text { graders improved } \\
\text { cross-sectionally with } \\
\text { later SSTs } \\
\text { No systematic effects } \\
\text { for individual subjects } \\
\text { of standardised test } \\
\text { scores cross- } \\
\text { sectionally }\end{array}$ \\
\hline $\begin{array}{l}\text { Wahl- } \\
\text { strom } \\
(2002) \\
64\end{array}$ & $\begin{array}{l}\frac{\text { Schools: } 7 \text { comprehensive high }}{\text { schools }} \\
\text { SST Change: } \\
\text { pre-change: } 7: 15 \\
\text { post-change: } 8: 40 \\
\text { Assessment: } 6 \text { years; data cover } 3 \\
\text { years before and after the change in } \\
\text { the 1997-1998 school year } \\
\text { Exposure time: } 3 \text { years } \\
\text { Sampling resolution: NA }\end{array}$ & $\begin{array}{l}N_{\text {students }}=\text { NA } \\
\text { Nobservations }=>1 \text { million } \\
\text { Grades levels: } 9^{\text {th }}-12^{\text {th }} \text { ? } \\
\frac{\text { Age: NA }}{\text { Gender ratio: NA }} \\
\frac{\text { Ethnicity/race: NA }}{\text { Location: Minneapolis, Minnesota, }}\end{array}$ & $\begin{array}{l}\text { Outcome: all letter grades } \\
\text { (semester and trimester grades) } \\
\text { Scale: categorical letter grading } \\
\text { Provided by: school district } \\
\text { administration }\end{array}$ & $\begin{array}{l}\text { Statistical analysis not } \\
\text { reported } \\
\text { Covariates: NA }\end{array}$ & $\begin{array}{l}\text { "A small improvement in grades earned } \\
\text { overall but not statistically significant" } \\
\text { No actual numbers are reported }\end{array}$ & $\begin{array}{l}\text { No effect on letter } \\
\text { grades }\end{array}$ \\
\hline $\begin{array}{l}\text { Author(s) } \\
\text { (Year) }\end{array}$ & Study Design & Sample characteristics & $\begin{array}{c}\text { Measure of } \\
\text { school achievement }\end{array}$ & Type of analysis & $\begin{array}{c}\text { Change in SSTs } \\
\text { results in }\end{array}$ & Key findings \\
\hline \multicolumn{7}{|c|}{ CROSS-SECTIONAL (between-subjects comparison) } \\
\hline $\begin{array}{l}\text { Groen \& } \\
\text { Pabilonia } \\
(2019) \\
58\end{array}$ & $\begin{array}{l}\text { Schools: } 790 \text { high schools } \\
\text { Data from the Child Development } \\
\text { Supplement to the Panel Study of } \\
\text { Income Dynamics (PSID-CDS) and } \\
\text { the Common Core of Data } \\
\text { SST Ranges: } \\
\text { from 07:00 to 09:15 } \\
\text { (average start time of 7:53) } \\
\text { Assessment: data from years } \\
\text { 2002/03 and 2007/08 } \\
\text { Exposure time: NA } \\
\text { Sampling resolution: once/year }\end{array}$ & $\begin{array}{l}N_{\text {students }}=\text { up to } 1200 \\
\text { Grade levels: } 9^{\text {th }}-12^{\text {th }} \\
\text { Age: } 13-18 \text { years } \\
\text { Gender ratio: } 50 \% \text { males } \\
\text { Ethnicity/race: White, Black, Asian, } \\
\text { Hispanic } \\
\text { Location: USA }\end{array}$ & $\begin{array}{l}\text { Outcome: broad-reading test } \\
\text { score and applied-problems } \\
\text { (math) test score; } \\
\text { both age-adjusted and from the } \\
\text { Woodcock-Johnson Revised Tests } \\
\text { of Basic Achievement } \\
\frac{\text { Scale: NA; normalised by survey }}{\text { year }} \\
\text { Provided by: NA (probably by } \\
\text { research assistant) }\end{array}$ & $\begin{array}{l}\text { Linear OLS model } \\
\text { predicting test scores; } \\
\text { Oster model (bounded } \\
\text { effects); instrumental- } \\
\text { variable estimates } \\
\text { Predictors: SST } \\
\text { Covariates: several on } \\
\text { student-level and school- } \\
\text { level, e.g. school day } \\
\text { length }\end{array}$ & $\begin{array}{l}\text { Per 1h delay: } \\
\text { increase in females' reading scores by } 0.16 \\
\text { SD ( } p<0.1) \text {; no sign. effect for females' } \\
\text { math scores and for both males' applied } \\
\text { problems and reading scores } \\
\text { From Oster model (bounded effects): } \\
0.16-0.28 \text { increase in reading for females; } \\
0.05-0.12 \text { increase in applied-problems for } \\
\text { males } \\
\rightarrow \text { probably mediated by an increase of } 36 \\
\text { min in sleep duration for every } 1 \text { h of later } \\
\text { SSTs for females but not for males }\end{array}$ & $\begin{array}{l}\text { Woodcock-Johnsons } \\
\text { Test scores increased } \\
\text { by up to } 0.28 \text { SD in } \\
\text { reading for females, } \\
\text { no significant effect } \\
\text { for males' scores } \\
\text { No significant effect } \\
\text { on applied-problems } \\
\text { scores for either } \\
\text { females or males }\end{array}$ \\
\hline
\end{tabular}




\begin{tabular}{|c|c|c|c|c|c|c|}
\hline \multirow[t]{3}{*}{$\begin{array}{l}\text { Hinrichs } \\
2011^{54}\end{array}$} & $\begin{array}{l}\text { Schools: } 48 \text { districts (73 schools) } \\
\text { Minneapolis and some suburbs } \\
\text { delayed (IG); St. Paul and other } \\
\text { suburbs maintained schedules (CG) } \\
\text { SST Change: } \\
\text { pre-change (IG): 7:15 } \\
\text { post-change (CG): 8:40 } \\
\text { SST in CG: 7:30 } \\
\text { Assessment: data span 1993-2002 } \\
\text { with change in 1997/1998 } \\
\text { Exposure time: } ~ 5 \text { years } \\
\text { Sampling resolution: once/year }\end{array}$ & $\begin{array}{l}\text { Nobservations }=196,617 \\
\text { Number of students not exactly } \\
\text { known, but slightly less than the } \\
\text { number of observations according to } \\
\text { author (private correspondence) } \\
\text { Grade levels: } 10^{\text {th }}-12^{\text {th }} \\
\frac{\text { Age: NA }}{\text { Gender ratio: }} 44 \% \text { males } \\
\text { Ethnicity/race: White, Black, Asian, } \\
\text { Hispanic, Other } \\
\text { Location: Twin Cities metropolitan } \\
\text { area, Minneapolis, USA }\end{array}$ & $\begin{array}{l}\text { Outcome: individual composite } \\
\text { ACT test scores } \\
\text { Scale: numeric; } 0-36 \text { (= best) } \\
\text { Provided by: ACT test company } \\
\text { with permission from schools }\end{array}$ & $\begin{array}{l}\text { OLS regression } \\
\text { predicting ACT scores } \\
\frac{\text { Predictors: SST, school }}{\text { day length }} \\
\text { Covariates: several on } \\
\text { student-level and } \\
\text { school/district-level }\end{array}$ & $\begin{array}{l}\text { No effect of SSTs on ACT scores (from full } \\
\text { specification): } \\
\text { 1h later SSTs: } 0.02 \text { SD, } p>0.05 \\
\text { Covariates: } \\
\text { Males: } b=0.25 \text { SD, } p<0.01 \\
\text { Black: } b=-2.47 \text { SD, } p<0.01 \\
\text { Low income: } b=-0.92 \text { SD, } p<0.01\end{array}$ & $\begin{array}{l}\text { No effect on ACT } \\
\text { scores }\end{array}$ \\
\hline & $\begin{array}{l}\text { Schools: every public high school in } \\
\text { Kansas state } \\
\text { SST Range: NA } \\
\text { Assessment: } 2000-2006\left(11^{\text {th }} \text { grade }\right. \\
\text { reading and } 10^{\text {th }} \text { grade maths } \\
\text { between 2001-2006; } 11^{\text {th }} \text { grade } \\
\text { social science and } 10^{\text {th }} \text { grade } \\
\text { science between } 2000-2006) \\
\text { Exposure time: NA } \\
\text { Sampling resolution: once/ year }\end{array}$ & $\begin{array}{l}\text { Nschools }=1,666 \\
\text { Grades: } 10^{\text {th }}-11^{\text {th }} \\
\text { Age: NA } \\
\text { Gender ratio: } 40 \% \text { white females, } 9 \% \\
\text { non-white females, } 9 \% \text { non-white } \\
\text { males } \\
\text { Ethnicity/race: white and non-white } \\
\text { Location: Kansas, USA }\end{array}$ & $\begin{array}{l}\text { Outcome: school-level test score } \\
\text { data on state-wide Kansas } \\
\text { Assessments in math, reading, } \\
\text { science and social studies } \\
\text { Scale: } 0-100 \% \text { (inferred, not } \\
\text { stated) } \\
\text { Provided by: Kansas Department } \\
\text { of Education }\end{array}$ & $\begin{array}{l}\text { OLS regression } \\
\text { predicting Kansas } \\
\text { assessment test scores } \\
\text { Covariates: several on } \\
\text { school-level variables }\end{array}$ & $\begin{array}{l}\text { No effect on any of the test scores (maths, } \\
\text { reading, science, or social studies) } \\
\text { For reading: } \\
1 \text { h later SSTs (from full specification): } \\
b=0.95, p>0.05\end{array}$ & $\begin{array}{l}\text { No effect on Kansas } \\
\text { Assessment scores in } \\
\text { math, reading, } \\
\text { science or social } \\
\text { studies }\end{array}$ \\
\hline & $\begin{array}{l}\text { Schools: } 75 \text { schools in } 19 \text { districts in } \\
\text { Virginia } \\
\text { SST Change: NA } \\
\text { Assessment: data span 2000-2007; } \\
\text { some delays in 2001/2002 } \\
\text { Exposure time: } ~ 6 \text { years } \\
\text { Sampling resolution: once/year }\end{array}$ & $\begin{array}{l}\text { Nobservations }=171 \text { (number of district- } \\
\text { by-year pairs) } \\
\text { Grade level/Age/Gender } \\
\text { ratio/Ethnicity/race: NA } \\
\text { Location: Virginia suburbs of } \\
\text { Washington, DC, USA }\end{array}$ & $\begin{array}{l}\text { Outcome: End of course exams } \\
\text { Scale: 0-100\% } \\
\text { Provided by: Virginia Department } \\
\text { of Education }\end{array}$ & $\begin{array}{l}\text { Analysis: OLS regression } \\
\text { predicting end of course } \\
\text { exams } \\
\text { Covariates: several on } \\
\text { school-level }\end{array}$ & $\begin{array}{l}\text { "The results, which are not reported here } \\
\text { but are available upon request, are } \\
\text { somewhat imprecise, but they do not give } \\
\text { evidence for an effect of the timing of the } \\
\text { school day on test scores." } \\
\rightarrow \text { requested and confirmed }\end{array}$ & $\begin{array}{l}\text { No effect on end of } \\
\text { course exams }\end{array}$ \\
\hline $\begin{array}{l}\text { Bastian \& } \\
\text { Fuller } \\
(2018)^{59}\end{array}$ & $\begin{array}{l}\text { Schools: } 410 \text { high schools; } 1,591 \\
\text { schools by year (includes all public } \\
\text { school students in North Carolina) } \\
\text { SST Range: } 7: 00 \text { to 9:30 } \\
23 \text { schools changed start times, } 9 \\
\text { changed start times by } \geq 30 \text { min }\end{array}$ & $\begin{array}{l}\text { Nstudents }=770,623 \\
\text { Grade level: } 9^{\text {th }}-12^{\text {th }} \text { (inferred) } \\
\text { Age: } 14-18 \text { years (inferred) } \\
\text { Gender ratio: NA }\end{array}$ & $\begin{array}{l}\text { Outcomes: } \\
\text { (1) Average course grades and } \\
\text { course grades in } 1^{\text {st }} \text { period classes } \\
\text { in math, English, science and } \\
\text { social studies } \\
\text { Scale: } 4 \text {-point scale }\end{array}$ & $\begin{array}{l}\text { Linear regression models } \\
\text { Covariates: several on } \\
\text { student-level and school- } \\
\text { level; incl. } \\
\text { year-fixed effects }\end{array}$ & $\begin{array}{l}\text { (1) Course grades: } \\
\text { Per } 1 \mathrm{~h} \text { delay: No effect of SSTs on overall } \\
\text { course grades } \beta=0.012, p>0.05 \\
\text { SSTs effect on course grades in } 1^{\text {st }} \text { period: } \\
\text { For } \geq 8: 30 \mathrm{~h} \text { starts (compared to }<7: 30 \mathrm{~h} \\
\text { start): } \beta=0.050, p<0.05\end{array}$ & $\begin{array}{l}\text { No significant } \\
\text { relationship between } \\
\text { SSTs and average } \\
\text { course grades } \\
\text { Grades in } 1^{\text {st }} \text { period } \\
\text { class were improved }\end{array}$ \\
\hline
\end{tabular}




\begin{tabular}{|c|c|c|c|c|c|c|}
\hline & $\begin{array}{l}44 \text { districts ( } 278 \text { schools) had } \\
\text { across-school variation in SSTs; } \\
\text { average time difference between } \\
\text { earliest and latest was } 33 \mathrm{~min} \text { ( } 5 \mathrm{~min} \\
\text { to max } 2 \mathrm{~h} \text { ); remaining } 69 \text { districts } \\
\text { (132 schools) had no variation } \\
\text { Assessment: data span school years } \\
\text { 2011-2012 through 2014-2015 } \\
\text { Exposure time: NA } \\
\text { Sampling resolution: NA; probably } \\
\text { once/year }\end{array}$ & $\begin{array}{l}\text { Ethnicity/race: White, Black, Hispanic, } \\
\text { American Indian, Asian, multiracial } \\
\text { Location: North Carolina, USA }\end{array}$ & $\begin{array}{l}\text { Conversation of numeric course } \\
\text { grades into unweighted grade } \\
\text { points } \\
\text { (2) Test scores from state wise } \\
\text { standardised end-of-course } \\
\text { exams (EOC) in algebra, biology, } \\
\text { English } \\
\text { Scale: normalised } \\
\text { (3) ACT composite scores } \\
\text { Scale: 0-36 } \\
\text { Provided by: North Carolina } \\
\text { Department of Public Instruction }\end{array}$ & $\begin{array}{l}\text { Specification checks with } \\
\text { school fixed effect and } \\
\text { with school district fixed } \\
\text { effects (=robustness } \\
\text { check of main results) }\end{array}$ & $\begin{array}{l}\text { Economically disadvantaged students, } \\
\text { minority and low-performing students } \\
\text { benefited more in course grades overall } \\
\text { and in } 1^{\text {st }} \text { period (per } 1 \mathrm{~h} \text { later): } \\
\beta=\text { from } 0.049 \text { to } 0.074, p>0.05 \text { or } 0.01 \\
\\
\text { (2) EOC scores: } \\
\text { Mixed results for EOC Algebra } \\
\text { (improvements but } p>0.05 .) \text {, EOC Biology } \\
\text { (reductions, } p<0.05) \text {, and EOC English } \\
\text { (reductions but } p>0.05 \text {.) } \\
\text { (3) ACT scores: } \\
\text { Per 1h delay: } \\
\text { overall SSTs effect on ACT composite: } \\
\beta=0.107, p>0.05 ; \\
\text { low-performing students: } \beta=0.277, p<0.05\end{array}$ & $\begin{array}{l}\text { by } 0.05 \text { quality points } \\
\text { associated with a } \\
\text { later start ( } \geq 8: 30 \mathrm{~h}) \\
\text { Later SSTs did not } \\
\text { systematically predict } \\
\text { EOC or ACT but low- } \\
\text { performing students } \\
\text { did better on the ACT } \\
\text { Later SSTs were } \\
\text { associated with } \\
\text { better course grades } \\
\text { (overall and } 1^{\text {st }} \\
\text { period) for } \\
\text { disadvantaged } \\
\text { students }\end{array}$ \\
\hline $\begin{array}{l}\text { Dunster } \\
\text { et al. } \\
(2018)^{60}\end{array}$ & $\begin{array}{l}\text { Schools: } 2 \text { public high schools (RHS } \\
\text { and FHS) } \\
\text { SST Change: } \\
\text { pre-change: } 07: 50 \\
\text { post-change: } 08: 45 \\
\text { Assessment: spring } 2016 \text { (pre) and } \\
\text { spring } 2017 \text { (post) } \\
\text { Exposure time: NA; } 7 \text { months? } \\
\frac{\text { Sampling resolution: once/year }}{\text { (second semester) }}\end{array}$ & $\begin{array}{l}\begin{array}{l}\text { Nstudents }=178 \\
\text { (pooled from both schools during } \\
\text { each year) }\end{array} \\
2 \text { independent samples: } \\
\text { Sample 2016: } n=51(\mathrm{RHS})+n=41(\mathrm{FHS}) \\
\text { Sample 2017: } n=41(\mathrm{RHS})+n=41(\mathrm{FHS}) \\
\text { Grade level: } 10^{\text {th }} \\
\text { Age: } \mu^{\sim} 16 \\
\text { Gender ratio: } ~ \\
\text { Ethnicity/race: White, Black, Asian, } \\
\text { African American, unknown/other } \\
\text { Location: Seattle, USA }\end{array}$ & $\begin{array}{l}\text { Outcome: One } 2^{\text {nd }} \text { semester } \\
\text { grade from a science lab class } \\
\text { Scale: NA (probably 0\%-100\%) } \\
\text { Provided by: teacher }\end{array}$ & $\begin{array}{l}\text { According to method } \\
\text { section: Generalized } \\
\text { linear models (binomial) } \\
\text { "with year as the } \\
\text { dependent variable, } \\
\text { testing the hypothesis } \\
\text { that years differed based } \\
\text { on the basis of the other } \\
\text { variables" } \\
\text { Other variables: school, } \\
\text { sleep offset, grade, } \\
\text { mood, chronotype, } \\
\text { sleepiness }\end{array}$ & $\begin{array}{l}\text { Years differed after controlling for } \\
\text { differences, including grade and sleep } \\
\text { variables } \\
\text { Median grade } 2016: 77.5 \% \\
\text { Mean grade } 2016: 74.6 \% \\
\text { Median grade } 2017: 82 \% \\
\text { Mean grade } 2017: 76.6 \%\end{array}$ & $\begin{array}{l}\text { Higher biology grades } \\
\text { were predictive of } \\
\text { years }\end{array}$ \\
\hline $\begin{array}{l}\text { Milić } \\
\text { et al. } \\
(2014) \\
53\end{array}$ & $\begin{array}{l}\text { Schools: } 4 \text { schools (2 grammar } \\
\text { schools and } 2 \text { vocational schools), } \\
\text { all with weekly alternating morning } \\
\text { and afternoon schedules } \\
\text { SST Schedules: } \\
\text { 2 schools with early schedule: } \\
\text { 07:00 (morning schedule) and 13:00 } \\
\text { (afternoon schedule) } \\
\text { 2 schools with late schedule: } \\
\text { 08:00 (morning schedule) and 14:00 } \\
\text { (afternoon schedule) } \\
\text { Assessment: May and June 2011 }\end{array}$ & $\begin{array}{l}\text { Nstudents= } 821 \\
\text { Sample Early schedule: } n=452 \\
\text { Sample Late schedule: } n=369 \\
\text { Grade levels: NA } \\
\text { Age: } 15-19 \text { years } \\
\text { Gender ratio: } \\
\text { across entire sample: } 54 \% \text { males } \\
\text { sample early schedule: } 73 \% \text { males } \\
\text { sample late schedule: } 30 \% \text { males } \\
\text { Ethnicity/race: NA } \\
\text { Location: Osijek, Croatia }\end{array}$ & $\begin{array}{l}\text { Outcome: Final grade in last } \\
\text { semester } \\
\text { Scale: numeric; } 1-5 \text { (= best) } \\
\text { Provided by: NA }\end{array}$ & $\begin{array}{l}\text { Mann-Whitney Test } \\
\text { Covariates: no }\end{array}$ & $\begin{array}{l}\text { Students attending the early schedule } \\
\text { obtained better grades }(p<0.001) \\
\text { SST at 07:00: } \\
\text { Mean grade: } 3.60(\text { SD } 1.08)=72.0 \% \\
\text { SST at 8:00: } \\
\text { Mean grade: } 3.28(\text { SD } 1.19)=65.6 \%\end{array}$ & $\begin{array}{l}\text { Final semester grades } \\
\text { were better in earlier } \\
\text { starting schools }\end{array}$ \\
\hline
\end{tabular}




\begin{tabular}{|c|c|c|c|c|c|c|}
\hline & $\begin{array}{l}\text { Exposure time: NA; probably since } \\
\text { admission to school } \\
\text { Sampling resolution: once }\end{array}$ & & & & & \\
\hline $\begin{array}{l}\text { Wolfson } \\
\text { et al. } \\
(2007) \\
61\end{array}$ & $\begin{array}{l}\text { Schools: } 2 \text { middle schools } \\
\text { SST Differences: } \\
\text { School E: 7:15 } \\
\text { School L: 8:37 } \\
\text { Assessment: fall 2003, spring } 2004 \\
\text { Exposure time: NA; probably since } \\
\text { admission to school (2-3 years?) } \\
\text { Sampling resolution: once }\end{array}$ & $\begin{array}{l}N_{\text {students }}=205 \\
\text { School E: } n=79 \\
\text { School L: } n=126 \\
\text { Grade levels: } 7^{\text {th }}(n=99)-8^{\text {th }}(n=106) \\
\text { Age: NA } \\
\text { Gender ratio: } 40 \% \text { males } \\
\text { Ethnicity/race: White, African } \\
\text { American, Hispanic, other } \\
\text { Location: New England, USA }\end{array}$ & $\begin{array}{l}\text { Outcome: average fall quarter } \\
\text { grade based on mean of } 4 \\
\text { subjects (English, science, math } \\
\text { and social studies) } \\
\text { Scale: numeric; } 0-100 \% \text { (= best) } \\
\text { Provided by: schools }\end{array}$ & $\begin{array}{l}\text { MANOVA, Bonferroni } \\
\text { correction for group } \\
\text { comparisons } \\
\frac{\text { Variables: school, grade, }}{\text { gender }} \\
\text { Other covariates: no, but } \\
\text { "schools were similar in } \\
\text { SES, size, and ethnic } \\
\text { distribution of students" } \\
\text { (except for a higher } \\
\text { percentage of Whites in } \\
\text { School L (60\% vs. 46\%) }\end{array}$ & $\begin{array}{l}\text { Significant School } x \text { Grade interaction: } \\
F(1,208)=17.06, p<0.001 ; \text { i.e. there were } \\
\text { no school differences for } 7^{\text {th }} \text { graders but } \\
8^{\text {th }} \text { graders } \\
\text { Students at School L had higher average } \\
\text { grades than students at School E: } \\
F(1,104)=10.60, p<0.01 ; \\
\text { SST at 7:15: } \\
\text { Mean grade: } 83.16 \% \text { (SD 7.16) } 7^{\text {th }} \text { graders } \\
\text { Mean grade: } 76.85 \% \text { (SD 9.45) } 8^{\text {th }} \text { graders } \\
\text { SST at 8:37: } \\
\text { Mean grade: } 80.46 \% \text { (SD 10.11) } 7^{\text {th }} \text { graders } \\
\text { Mean grade: } 83.79 \% \text { (SD 8.80) } 8^{\text {th }} \text { graders } \\
\text { No gender differences were found }\end{array}$ & $\begin{array}{l}\text { Increased averaged } \\
\text { fall quarter grades for } \\
8^{\text {th }} \text { graders in later } \\
\text { school } \\
\text { No significant } \\
\text { difference for } 7^{\text {th }} \\
\text { graders }\end{array}$ \\
\hline $\begin{array}{l}\text { Lewin } \\
\text { et al. } \\
(2017) \\
69\end{array}$ & $\begin{array}{l}\text { Schools: } 26 \text { middle schools with } \\
\text { variable SSTs } \\
\text { (country wide surveillance data) } \\
\text { SST Ranges: } \\
\text { "Earliest" SSTs: 7:20-7:30 } \\
\text { "Early" SSTs: 7:40-7:55 } \\
\text { "Late" SSTs: 8:00-8:10 } \\
\text { Assessment: surveys in 2008, 2010, } \\
\text { and 2012 } \\
\text { Exposure time: NA; probably since } \\
\text { admission to school (3 years?) } \\
\text { Sampling resolution: once/time } \\
\text { point }\end{array}$ & $\begin{array}{l}\text { Nstudents 32,000 } \\
\text { Pooled from all sample years } \\
\text { Sample 2008: } n=6,936 \\
\text { Sample 2010: } n=11,991 \\
\text { Sample 2012: } n=10,768 \\
\text { Sample "Earliest" SSTs: } n=7,206 \\
\text { Sample "Early" SSTs: } n=13,161 \\
\text { Sample "Late" SSTs: } n=12,613 \\
\text { Grade levels: } \text { : }^{\text {th }} \\
\text { Age: } 13-14 \text { years } \\
\text { Gender ratio: } 49.8 \% \text { males } \\
\text { Ethnicity/race: White, non-white } \\
\text { Location: NA but most likely USA }\end{array}$ & $\begin{array}{l}\text { Outcome: Self-reported grades } \\
\text { Scale: 4-point categorical; "Do } \\
\text { you mainly get A's, B's, C's, or } \\
\text { D's/F's?" } \\
\text { Provided by: participant }\end{array}$ & $\begin{array}{l}\begin{array}{l}\text { Path analysis with probit } \\
\text { regression predicting } \\
\text { grades: }\end{array} \\
\text { Predictor: SSTs } \\
\text { Mediator: sleep duration } \\
\text { (Sobel test) } \\
\text { Covariates student-level: } \\
\text { survey year, gender, race } \\
\text { Covariates school-level: } \\
\text { free lunch status } \\
\text { Hierarchical structure: } \\
\text { students nested within } \\
\text { schools }\end{array}$ & $\begin{array}{l}\text { Self-reported grades of students attending } \\
\text { the "earliest schools" were significantly } \\
\text { lower ( } \beta=-0.286, p=0.012) \text {, no sign. effect } \\
\text { for "earlier schools" ( } \beta=-0.114, p=0.126 \text { ) } \\
\text { The negative effect of SST on grades was } \\
\text { overall mediated by sleep duration: } \\
\beta=0.115, p<0.001 \\
\text { Covariates: } \\
\text { Female: } \beta=0.312, p<0.001 \\
\text { Non-white: } \beta=-0.321, p<0.001 \\
\text { Free lunch status: up to } \beta=-0.668, p<0.001\end{array}$ & $\begin{array}{l}\text { An advance of at least } \\
30 \text { min was } \\
\text { associated with worse } \\
\text { self-reported grades } \\
\text { Longer sleep duration } \\
\text { was also associated } \\
\text { with increased grades }\end{array}$ \\
\hline $\begin{array}{l}\text { Wahl- } \\
\text { strom } \\
1997^{62}\end{array}$ & $\begin{array}{l}\text { Schools: } 3 \text { districts; } 1 \text { delayed SSTs, } \\
2 \text { did not delay; high schools and } \\
\text { middle schools } \\
\text { SST Ranges: } \\
\text { High schools (10-12 } 12^{\text {th }} \text { grades): } \\
\text { SST at district A (IG): } 8: 30 \\
\text { SST at district B: } 7: 25 \\
\text { SST at district C: } 7: 15\end{array}$ & $\begin{array}{l}\text { Nstudents= a not further defined } \\
\text { sample was drawn from } 7,168 \\
\text { students of } 17 \text { districts } \\
\text { Grade levels: } 10^{\text {th }}-12^{\text {th }} \text { and } 7^{\text {th }}-8^{\text {th }} \\
\text { Age: NA } \\
\text { Gender ratio: NA } \\
\text { Ethnicity/race: NA } \\
\text { Location: Minnesota, USA }\end{array}$ & $\begin{array}{l}\text { Outcome: Self-reported grades } \\
\text { Scale: NA } \\
\text { Provided by: participants }\end{array}$ & $\begin{array}{l}\text { Statistical analysis: NA } \\
\text { Covariates: NA }\end{array}$ & $\begin{array}{l}\text { Mean self-reported grades in district } A \\
\text { were highest }(p<0.05) \text { compared to district } \\
\text { B and } C \text { for } 10-12^{\text {th }} \text { graders: } \\
\text { District A: } 7.08 \\
\text { District } B: 6.50 \\
\text { District } C: 6.37 \\
\text { But not for } 7-8^{\text {th }} \text { graders: } \\
\text { District } A: 6.66\end{array}$ & $\begin{array}{l}\text { Students in a district } \\
\text { with later start time } \\
\text { reported getting } \\
\text { higher grades than in } \\
\text { two districts with } \\
\text { earlier SSTs } \\
\text { (high schools) }\end{array}$ \\
\hline
\end{tabular}




\begin{tabular}{|c|c|c|c|c|c|c|}
\hline & $\begin{array}{l}\text { Middle schools }\left(7-8^{\text {th }} \text { grade): }\right. \\
\text { SST at district A (IG): 7:35 } \\
\text { SST at district B: 8:00 } \\
\text { SST at district C: } 8: 00 \\
\text { Assessment: NA } \\
\text { Exposure time: NA } \\
\text { Sampling resolution: NA }\end{array}$ & & & & $\begin{array}{l}\text { District B: } 6.91 \\
\text { District C: } 6.60\end{array}$ & $\begin{array}{l}\text { For middle schools, } \\
\text { students who started } \\
\text { later were either } \\
\text { better or similar to } \\
\text { students from a } \\
\text { school which started } \\
\text { earlier }\end{array}$ \\
\hline $\begin{array}{l}\text { Kelley } \\
\text { et al. } \\
\text { (2017) } \\
68\end{array}$ & $\begin{array}{l}\text { School: } 1 \text { English state-funded high } \\
\text { school } \\
\text { SST Change: } \\
\text { Year 0 = pre-change (A): 08:50 } \\
\text { Year 1-2 = post-change (B): 10:00 } \\
\text { Year 3 = change back (A): 08:50 } \\
\text { Assessment: } 4 \text { years } \\
\text { Exposure time: } 1-2 \text { years } \\
\text { Sampling resolution: once/year }\end{array}$ & $\begin{array}{l}\text { Year 0: } n_{\text {students }}=169 \\
\text { Year 1: } n_{\text {tudents }}=166 \\
\text { Year 2: } n_{\text {tudents }}=164 \\
\text { Year 3: } n_{\text {tudents }}=179 \\
\text { Grade levels: NA } \\
\text { Age: } 14-16 \\
\text { Gender ratio: NA } \\
\text { Ethnicity/race: NA } \\
\text { Location: urban-area of } 0.7 \text { million in } \\
\text { a region where achievement was } \\
\text { lower than national average, England }\end{array}$ & $\begin{array}{l}\text { Outcome: Standard National } \\
\text { Examination (GCSE) } \\
\text { Scale: G-A* (= best) } \\
\text { Provided by: UK Office of National } \\
\text { Statistics }\end{array}$ & $\begin{array}{l}\text { T-test; Cohen's } d \text { and } \mathrm{h} \\
\text { for effect size } \\
\text { Value-added analysis } \\
\text { (predictions) } \\
\text { Percentage of students } \\
\text { achieving "good } \\
\text { academic progress" (= } \\
\text { achieving } 5 \text { or more } \\
\text { GCSE grades of C or } \\
\text { better in English, math } \\
\text { and at least } 3 \text { other } \\
\text { subjects) } \\
\text { Covariates: NA }\end{array}$ & $\begin{array}{l}\text { Change in value-added as } \% \text { of national } \\
\text { (compared to national average): } \\
\text { Year } 1 \text { vs } 0:+15 \%, p<0.0005 \\
\text { Year } 2 \text { vs } 0:+20 \%, p<0.0005, \\
\text { Year } 3 \text { vs } 2:-7 \%, p<0.0005 \\
\text { Percentage of students making good } \\
\text { academic progress compared to national } \\
\text { average: } \\
\text { Year 0: }-40 \%, p<0.005 \\
\text { Year 1: }-9 \%, p=0.182 \\
\text { Year } 2:-11 \%, p=0.081 \\
\text { Year 3: }-15 \%, p=0.014\end{array}$ & $\begin{array}{l}\text { Delay is associated } \\
\text { with higher \% of } \\
\text { students making good } \\
\text { academic progress } \\
\text { and higher value- } \\
\text { added number } \\
\text { compared to national } \\
\text { average }\end{array}$ \\
\hline $\begin{array}{l}\text { Wahl- } \\
\text { strom } \\
\text { (2014) } \\
63\end{array}$ & $\begin{array}{l}\text { Schools: } 8 \text { public high schools in } 5 \\
\text { school districts in } 3 \text { states changed } \\
\text { SSTs and participated in a survey on } \\
\text { sleep habits } \\
\text { Grades were retrieved from } 6 \\
\text { schools in } 3 \text { districts } \\
\text { SST Change: } \\
\text { pre-change: 7:35-7:50 } \\
\text { post-change: 8:00-8:55 } \\
\text { Assessment: 2010-2011 } \\
\text { (Minnesota), 2011-2012 (Colorado); } \\
\text { 2011-2012 (pre-change in } \\
\text { Wyoming) vs 2012-2013 (post } \\
\text { change in Wyoming) } \\
\text { Exposure time: } 1 \text { year? } \\
\text { Sampling resolution: once/time } \\
\text { point }\end{array}$ & $\begin{array}{l}N_{\text {students }}=9,089 \text { (sleep habits survey) } \\
N_{\text {students: NA (grade analyses) }} \\
\frac{\text { Grade levels: }}{\text { Age: } 13-19} \text {-12 } \\
\text { Gender ratio: } \\
\text { Ethnicity/race: White, Black/African } \\
\text { American, Hispanic/Latino, } \\
\text { Asian/Asian American, Other } \\
\text { Location: } \\
\text { Minnesota/Colorado/Wyoming, USA }\end{array}$ & $\begin{array}{l}\text { Outcomes: } \\
\text { (1) Grades in English, maths, } \\
\text { social studies, science in } 1^{\text {st }} \text { and } \\
3^{\text {rd }} \text { period-classes or GPAs } \\
\text { Scale: categorical; "mostly A's=9" } \\
\text { to “mostly F's" }=1 \\
\text { (2) Standardised test scores } \\
\text { (state-wide achievement tests or } \\
\text { PLAN) } \\
\text { Scale: NA } \\
\text { Provided by: GPAs from districts; } \\
\text { categorical grades by students }\end{array}$ & $\begin{array}{l}\text { t-tests, correlations } \\
\text { Covariates: NA }\end{array}$ & $\begin{array}{l}\text { Longitudinal standardised test scores: } \\
\text { mainly non-significant results and some } \\
\text { mixed results for both composite scores } \\
\text { (PLAN) and individual subjects }\end{array}$ & $\begin{array}{l}\text { Mixed and often non- } \\
\text { significant effects on } \\
\text { GPAs and } \\
\text { standardised test } \\
\text { scores }\end{array}$ \\
\hline
\end{tabular}


medRxiv preprint doi: https://doi.org/10.1101/2021.05.19.21252346; this version posted May 20, 2021. The copyright holder for this preprint (which was not certified by peer review) is the author/funder, who has granted medRxiv a license to display the preprint in perpetuity.

It is made available under a CC-BY-NC-ND 4.0 International license .

\section{Supplementary information for}

"School start times and academic achievement - a systematic review on grades and test scores"

\section{Authors:}

Anna M. Biller, Karin Meissner, Eva C. Winnebeck \& Giulia Zerbini

\section{Corresponding authors:}

anna.biller@med.uni-muenchen.de

giulia.zerbini@med.uni-augsburg.de 
medRxiv preprint doi: https://doi.org/10.1101/2021.05.19.21252346; this version posted May 20, 2021. The copyright holder for this preprint

(which was not certified by peer review) is the author/funder, who has granted medRxiv a license to display the preprint in perpetuity.

It is made available under a CC-BY-NC-ND 4.0 International license.

Tab. S1 | Protocol detailing reasons for risk of bias assessment decisions of Tab. 1.

\begin{tabular}{|c|c|c|c|}
\hline Study & Bias & Decision & Reasons \\
\hline \multirow[t]{6}{*}{$\begin{array}{l}\text { Edwards } \\
2012^{55}\end{array}$} & Reporting bias on author level & Green & $\begin{array}{l}\text { Sample characteristics are well described; actual sample size for the } \\
\text { different analyses is not always clear. Statistical analyses and models } \\
\text { are well described; the model equations, p-values and beta } \\
\text { coefficients are reported }\end{array}$ \\
\hline & Responder bias on student level & Green & Data objectively reported \\
\hline & Blinding & Green & Data retrieved from archive \\
\hline & $\begin{array}{l}\text { (Dis)similarity of baseline } \\
\text { characteristics }\end{array}$ & Green & Many variables considered and analysed in association with SSTs \\
\hline & $\begin{array}{l}\text { Appropriate statistical models } \\
\text { which control for confounders }\end{array}$ & Green & Yes \\
\hline & Control group present & Orange & $\begin{array}{l}\text { State-wide data are used to construct percentile scores for each } \\
\text { student within their grade and current year; no direct comparison } \\
\text { with the national average }\end{array}$ \\
\hline \multirow[t]{6}{*}{$\begin{array}{l}\text { Jung } \\
2018^{65}\end{array}$} & Reporting bias on author level & Green & $\begin{array}{l}\text { Sample characteristics are well described. Statistical analyses and } \\
\text { models are well described; the model equations, } p \text {-values and beta } \\
\text { coefficients are reported }\end{array}$ \\
\hline & Responder bias on student level & Green & Data objectively reported \\
\hline & Blinding & Green & Data retrieved from archive \\
\hline & $\begin{array}{l}\text { (Dis)similarity of baseline } \\
\text { characteristics }\end{array}$ & Green & Many variables considered and analysed in association with SSTs \\
\hline & $\begin{array}{l}\text { Appropriate statistical models } \\
\text { which control for confounders }\end{array}$ & Green & Yes \\
\hline & Control group present & Green & Yes \\
\hline \multirow[t]{6}{*}{$\begin{array}{l}\text { Kim } \\
2018^{67}\end{array}$} & Reporting bias on author level & Orange & $\begin{array}{l}\text { Sample characteristics are not well described. Statistical analyses and } \\
\text { models are well described; the model equations, } p \text {-values and beta } \\
\text { coefficients are reported. }\end{array}$ \\
\hline & Responder bias on student level & Green & Data objectively reported \\
\hline & Blinding & Green & Data retrieved from archive \\
\hline & $\begin{array}{l}\text { (Dis)similarity of baseline } \\
\text { characteristics }\end{array}$ & Green & $\begin{array}{l}\text { Many variables considered and analysed in association with SSTs. The } \\
\text { EDSS provided a } 70 \% \text { randomly extracted sample from the } \\
\text { population (includes } 3 \text { exam scores, gender and school ID) }\end{array}$ \\
\hline & $\begin{array}{l}\text { Appropriate statistical models } \\
\text { which control for confounders }\end{array}$ & Green & Yes \\
\hline & Control group present & Green & Yes \\
\hline \multirow[t]{6}{*}{$\begin{array}{l}\text { Rhie } \\
2018^{66}\end{array}$} & Reporting bias on author level & Orange & $\begin{array}{l}\text { Sample characteristics are well described but some information is } \\
\text { contradictory (cfr Table } 1 \text { and Table } \mathrm{S} 1 \text { grade } 7^{\text {th }} \text { to } 11^{\text {th }} \text { or } 12^{\text {th }} \text { ). } \\
\text { Statistical analyses are not fully reported. P values are reported but } \\
\text { statistical tests are not reported. Overall there is no effect of the } \\
9 \text { AM policy, but the third sentence of the discussion says: "Self- } \\
\text { reported school performance } \\
\text { of the intervention group was more improved than the control". This } \\
\text { analysis is not reported and it is contradictory with the rest of the } \\
\text { results }\end{array}$ \\
\hline & Responder bias on student level & Red & Grades are self-reported \\
\hline & Blinding & Red & $\begin{array}{l}\text { Students were aware they were participating in the experiment (they } \\
\text { had to fill in questionnaires) }\end{array}$ \\
\hline & $\begin{array}{l}\text { (Dis)similarity of baseline } \\
\text { characteristics }\end{array}$ & Green & $\begin{array}{l}\text { Considered (in terms of sleep onset, sleep offset and sleep duration; } \\
\text { not for gender) }\end{array}$ \\
\hline & $\begin{array}{l}\text { Appropriate statistical models } \\
\text { which control for confounders }\end{array}$ & Orange & $\begin{array}{l}\text { No. The authors used a logistic regression with complex samples } \\
\text { comparing each year to a baseline year, and for intervention and } \\
\text { control group but no covariates were included }\end{array}$ \\
\hline & Control group present & Green & Yes \\
\hline $\begin{array}{l}\text { Lenard } \\
2020^{56}\end{array}$ & Reporting bias on author level & Green & $\begin{array}{l}\text { Sample characteristics are well described. Statistical analyses and } \\
\text { models are well described; the model equations, } p \text {-values and beta } \\
\text { coefficients are reported }\end{array}$ \\
\hline
\end{tabular}


medRxiv preprint doi: https://doi.org/10.1101/2021.05.19.21252346; this version posted May 20, 2021. The copyright holder for this preprint

(which was not certified by peer review) is the author/funder, who has granted medRxiv a license to display the preprint in perpetuity.

It is made available under a CC-BY-NC-ND 4.0 International license .

\begin{tabular}{|c|c|c|c|}
\hline & Responder bias on student level & Green & Data objectively reported (ACT scores) \\
\hline & Blinding & Green & Data retrieved from archive \\
\hline & $\begin{array}{l}\text { (Dis)similarity of baseline } \\
\text { characteristics }\end{array}$ & Green & Many variables considered and analysed in association with SSTs \\
\hline & $\begin{array}{l}\text { Appropriate statistical models } \\
\text { which control for confounders }\end{array}$ & Green & Yes \\
\hline & Control group present & Green & Yes \\
\hline \multirow[t]{6}{*}{$\begin{array}{l}\text { Shin } \\
2018^{48}\end{array}$} & Reporting bias on author level & Orange & $\begin{array}{l}\text { Sample characteristics are not well described. Statistical analyses and } \\
\text { models are well described; the model equations, } p \text {-values and beta } \\
\text { coefficients are reported. }\end{array}$ \\
\hline & Responder bias on student level & Green & Data objectively reported \\
\hline & Blinding & Green & Data retrieved from archive \\
\hline & $\begin{array}{l}\text { (Dis)similarity of baseline } \\
\text { characteristics }\end{array}$ & Green & Many variables considered and analysed in association with SSTs \\
\hline & $\begin{array}{l}\text { Appropriate statistical models } \\
\text { which control for confounders }\end{array}$ & Green & Yes \\
\hline & Control group present & Green & Yes \\
\hline \multicolumn{4}{|c|}{ LONGITUDINAL STUDIES WITHOUT CONTROL GROUP (within-subjects comparison) } \\
\hline Study & Bias & Decision & Reasons \\
\hline \multirow[t]{5}{*}{$\begin{array}{l}\text { Biller } \\
2021^{49}\end{array}$} & Reporting bias on author level & Green & $\begin{array}{l}\text { All information necessary to critically read the results are reported } \\
\text { (sample information, school schedule, statistical analyses) }\end{array}$ \\
\hline & Responder bias on student level & Green & Data objectively reported \\
\hline & Blinding & Red & $\begin{array}{l}\text { Even though grades were obtained objectively from the school } \\
\text { registry, students were aware they were participating in the } \\
\text { experiment (they had to fill in questionnaires) }\end{array}$ \\
\hline & $\begin{array}{l}\text { Appropriate statistical models } \\
\text { which control for confounders }\end{array}$ & Green & Yes \\
\hline & Control group present & Red & No \\
\hline \multirow{5}{*}{$\begin{array}{l}\text { Boergers } \\
2014^{51}\end{array}$} & Reporting bias on author level & Red & Statistical analyses regarding grades are not reported \\
\hline & Responder bias on student level & Red & Grades are self-reported \\
\hline & Blinding & Red & $\begin{array}{l}\text { Students were aware they were participating in the experiment (they } \\
\text { had to fill in questionnaires) }\end{array}$ \\
\hline & $\begin{array}{l}\text { Appropriate statistical models } \\
\text { which control for confounders }\end{array}$ & Red & Unable to judge due to missing information \\
\hline & Control group present & Red & No \\
\hline \multirow[t]{5}{*}{$\begin{array}{l}\text { Owens } \\
2010^{52}\end{array}$} & Reporting bias on author level & Green & $\begin{array}{l}\text { All information necessary to critically read the results are reported } \\
\text { (sample information, school schedule, statistical analyses). Ethnicity } \\
\text { is missing }\end{array}$ \\
\hline & Responder bias on student level & Red & Grades are self-reported \\
\hline & Blinding & Red & $\begin{array}{l}\text { Students were aware they were participating in the experiment (they } \\
\text { had to fill in questionnaires) }\end{array}$ \\
\hline & $\begin{array}{l}\text { Appropriate statistical models } \\
\text { which control for confounders }\end{array}$ & Red & Simple Chi-Square Test not controlling for confounders \\
\hline & Control group present & Red & No \\
\hline \multirow[t]{5}{*}{$\begin{array}{l}\text { Thacher } \\
2016^{57}\end{array}$} & Reporting bias on author level & Green & $\begin{array}{l}\text { All information necessary to critically read the results are reported } \\
\text { (sample information, school schedule, statistical analyses) }\end{array}$ \\
\hline & Responder bias on student level & Green & Data objectively reported \\
\hline & Blinding & Red & $\begin{array}{l}\text { Students were aware they were participating in the experiment (they } \\
\text { had to fill in questionnaires) }\end{array}$ \\
\hline & $\begin{array}{l}\text { Appropriate statistical models } \\
\text { which control for confounders }\end{array}$ & Orange & $\begin{array}{l}\text { The longitudinal analysis is appropriate (mixed linear model with } \\
\text { some moderators/covariates); cross-sectional analyses are only } \\
\text { simple t-tests; it is not clear why the authors do not run a mixed } \\
\text { within-between model and combine longitudinal and cross-sectional } \\
\text { analyses. Nevertheless, several analyses are reported which supports } \\
\text { the notion that the data were extensively explored to reach the } \\
\text { conclusions of the paper }\end{array}$ \\
\hline & Control group present & Red & No \\
\hline
\end{tabular}


medRxiv preprint doi: https://doi.org/10.1101/2021.05.19.21252346; this version posted May 20, 2021. The copyright holder for this preprint

(which was not certified by peer review) is the author/funder, who has granted medRxiv a license to display the preprint in perpetuity.

It is made available under a CC-BY-NC-ND 4.0 International license .

\begin{tabular}{|c|c|c|c|}
\hline $\begin{array}{l}\text { Wahl- } \\
\text { strom } \\
2002^{64}\end{array}$ & Reporting bias on author level & Red & $\begin{array}{l}\text { Sample size (n students) for the grade analyses not reported, } \\
\text { statistical analyses not reported, demographic characteristics of the } \\
\text { sample not fully reported; author(s) were contacted but did not } \\
\text { respond }\end{array}$ \\
\hline & Responder bias on student level & Green & Data objectively reported \\
\hline & Blinding & Orange & $\begin{array}{l}\text { Students were aware they were participating in the experiment (they } \\
\text { had to fill in questionnaires) but grades were collected also in } \\
\text { students who did not fill in questionnaires }\end{array}$ \\
\hline & $\begin{array}{l}\text { Appropriate statistical models } \\
\text { which control for confounders }\end{array}$ & Red & Incomplete information to judge \\
\hline & Control group present & Red & No \\
\hline \multicolumn{4}{|c|}{ CROSS-SECTIONAL STUDIES (between subject comparison) } \\
\hline Study & Bias & Decision & Reasons \\
\hline \multirow[t]{5}{*}{$\begin{array}{l}\text { Groen } \\
2019^{58}\end{array}$} & Reporting bias on author level & Green & $\begin{array}{l}\text { Statistical analyses overall are well described. Only analyses } \\
\text { regarding results in Table } 1 \text { are not reported; not always specified } \\
\text { that the statistically significant results were at the } 0.1 \text { level }\end{array}$ \\
\hline & Responder bias on student level & Green & Data objectively reported \\
\hline & Blinding & Green & Data retrieved from archive \\
\hline & $\begin{array}{l}\text { (Dis)similarity of baseline } \\
\text { characteristics }\end{array}$ & Green & Many variables considered and analysed in association with SSTs \\
\hline & $\begin{array}{l}\text { Appropriate statistical models } \\
\text { which control for confounders }\end{array}$ & Green & Yes \\
\hline \multirow{5}{*}{$\begin{array}{l}\text { Hinrichs } \\
2011^{54}\end{array}$} & Reporting bias on author level & Green & Originally orange but author provided all details after contacting \\
\hline & Responder bias on student level & Green & Data objectively reported \\
\hline & Blinding & Green & Data retrieved from archive \\
\hline & $\begin{array}{l}\text { (Dis)similarity of baseline } \\
\text { characteristics }\end{array}$ & Green & Many variables considered and analysed in association with SSTs \\
\hline & $\begin{array}{l}\text { Appropriate statistical models } \\
\text { which control for confounders }\end{array}$ & Green & Yes \\
\hline \multirow[t]{5}{*}{$\begin{array}{l}\text { Bastian } \\
2018^{59}\end{array}$} & Reporting bias on author level & Green & $\begin{array}{l}\text { Statistical analyses and models are well described; the model } \\
\text { equations, p-values and beta coefficients are reported. }\end{array}$ \\
\hline & Responder bias on student level & Green & Data objectively reported \\
\hline & Blinding & Green & Data retrieved from archive \\
\hline & $\begin{array}{l}\text { (Dis)similarity of baseline } \\
\text { characteristics }\end{array}$ & Green & Many variables considered and analysed in association with SSTs \\
\hline & $\begin{array}{l}\text { Appropriate statistical models } \\
\text { which control for confounders }\end{array}$ & Green & Yes \\
\hline \multirow[t]{5}{*}{$\begin{array}{l}\text { Dunster } \\
2018^{60}\end{array}$} & Reporting bias on author level & Green & $\begin{array}{l}\text { Information about sample and study design are well described. } \\
\text { Statistical analyses are well described but are contradictory reported } \\
\text { in the methods and in the results. Only p-values are reported and not } \\
\text { the statistical tests performed. }\end{array}$ \\
\hline & Responder bias on student level & Green & Data objectively reported \\
\hline & Blinding & Red & $\begin{array}{l}\text { Students were aware they were participating in the experiment, and } \\
\text { teachers who provided the grades as well (the authors also recognize } \\
\text { a potential teacher-level bias) }\end{array}$ \\
\hline & $\begin{array}{l}\text { (Dis)similarity of baseline } \\
\text { characteristics }\end{array}$ & Orange & $\begin{array}{l}\text { Variables such as ethnicity and other possible confounders were } \\
\text { assessed but not considered in the analyses; higher percentage of } \\
\text { whites were found in } 2017 \text { sample }\end{array}$ \\
\hline & $\begin{array}{l}\text { Appropriate statistical models } \\
\text { which control for confounders }\end{array}$ & Orange & $\begin{array}{l}\text { Better grades were predictive of school year but this was after } \\
\text { accounting for other predictive variables. Authors thus tested year } \\
\text { and not grade as dependent variable. }\end{array}$ \\
\hline \multirow[t]{2}{*}{$\begin{array}{l}\text { Milic } \\
2014^{53}\end{array}$} & Reporting bias on author level & Green & $\begin{array}{l}\text { All information necessary to critically read the results are reported } \\
\text { (sample information, school schedule, statistical analyses) }\end{array}$ \\
\hline & Responder bias on student level & Orange & $\begin{array}{l}\text { Grades are possibly subjectively reported from questionnaires but } \\
\text { this is unclear; author(s) were contacted but did not respond }\end{array}$ \\
\hline
\end{tabular}


medRxiv preprint doi: https://doi.org/10.1101/2021.05.19.21252346; this version posted May 20, 2021. The copyright holder for this preprint

(which was not certified by peer review) is the author/funder, who has granted medRxiv a license to display the preprint in perpetuity.

It is made available under a CC-BY-NC-ND 4.0 International license.

\begin{tabular}{|c|c|c|c|}
\hline & Blinding & Red & $\begin{array}{l}\text { Students were aware they were participating in the experiment (they } \\
\text { had to fill in questionnaires) }\end{array}$ \\
\hline & $\begin{array}{l}\text { (Dis)similarity of baseline } \\
\text { characteristics }\end{array}$ & Orange & $\begin{array}{l}\text { The different gender composition of the early schedule and late } \\
\text { schedule samples is reported and discussed but not controlled for in } \\
\text { the analyses }\end{array}$ \\
\hline & $\begin{array}{l}\text { Appropriate statistical models } \\
\text { which control for confounders }\end{array}$ & Red & Simple Mann-Whitney Test without controlling for confounders \\
\hline \multirow[t]{5}{*}{$\begin{array}{l}\text { Wolfson } \\
200761\end{array}$} & Reporting bias on author level & Green & $\begin{array}{l}\text { All information necessary to critically read the results are reported } \\
\text { (sample information, school schedule, statistical analyses) }\end{array}$ \\
\hline & Responder bias on student level & Green & Data objectively reported \\
\hline & Blinding & Red & $\begin{array}{l}\text { Students were aware they were participating in the experiment (they } \\
\text { had to fill in questionnaires) }\end{array}$ \\
\hline & $\begin{array}{l}\text { (Dis)similarity of baseline } \\
\text { characteristics }\end{array}$ & Orange & $\begin{array}{l}\text { Schools are very similar, except for a higher percentage of white } \\
\text { students in the school with later SSTs }\end{array}$ \\
\hline & $\begin{array}{l}\text { Appropriate statistical models } \\
\text { which control for confounders }\end{array}$ & Orange & $\begin{array}{l}\text { MANOVA with Bonferroni correction for multiple comparisons. One } \\
\text { problem is that ethnicity was not controlled for although there were } \\
\text { more white students in the school with later SSTs. }\end{array}$ \\
\hline \multirow{5}{*}{$\begin{array}{l}\text { Wahl- } \\
\text { strom } \\
1997^{62} \\
\end{array}$} & Reporting bias on author level & Red & $\begin{array}{l}\text { All information necessary to critically read the results are missing } \\
\text { (sample information, statistical analyses etc.) }\end{array}$ \\
\hline & Responder bias on student level & Red & Grades are self-reported \\
\hline & Blinding & Red & $\begin{array}{l}\text { Students were aware they were participating in the experiment (they } \\
\text { had to fill in questionnaires) }\end{array}$ \\
\hline & $\begin{array}{l}\text { (Dis)similarity of baseline } \\
\text { characteristics }\end{array}$ & Orange & $\begin{array}{l}\text { The author reports that the schools are similar but data are not } \\
\text { reported. One caveat is that students from district B and C also spent } \\
\text { more time on homework. }\end{array}$ \\
\hline & $\begin{array}{l}\text { Appropriate statistical models } \\
\text { which control for confounders }\end{array}$ & Red & Insufficient information to be judged \\
\hline \multirow[t]{5}{*}{$\begin{array}{l}\text { Lewin } \\
2017^{69}\end{array}$} & Reporting bias on author level & Green & $\begin{array}{l}\text { All information necessary to critically read the results are reported } \\
\text { (sample information, school schedule, statistical analyses) }\end{array}$ \\
\hline & Responder bias on student level & Red & Grades are self-reported \\
\hline & Blinding & Red & $\begin{array}{l}\text { Students were aware they were participating in the experiment (they } \\
\text { had to fill in questionnaires) }\end{array}$ \\
\hline & $\begin{array}{l}\text { (Dis)similarity of baseline } \\
\text { characteristics }\end{array}$ & Green & Reported and controlled for \\
\hline & $\begin{array}{l}\text { Appropriate statistical models } \\
\text { which control for confounders }\end{array}$ & Green & Yes \\
\hline \multirow[t]{4}{*}{$\begin{array}{l}\text { Wahl- } \\
\text { strom } \\
2014^{63}\end{array}$} & Reporting bias on author level & Red & $\begin{array}{l}\text { Sample size (n students) for the grade analyses are not reported; } \\
\text { statistical analyses are not reported (t-test, } p \text {-values); the average } \\
\text { GPAs before and after the change are only reported in the appendix } \\
\text { but without specifying the SD and range and therefore it is difficult to } \\
\text { judge the effect size }\end{array}$ \\
\hline & Responder bias on student level & Green & $\begin{array}{l}\text { Grades are probably objectively reported (GPAs and test scores); } \\
\text { author(s) were contacted but did not respond }\end{array}$ \\
\hline & Blinding & Red & $\begin{array}{l}\text { Students were aware they were participating in the experiment (they } \\
\text { had to fill in questionnaires). The authors do not report whether } \\
\text { grades were collected also in other students that did not fill in } \\
\text { questionnaires. }\end{array}$ \\
\hline & $\begin{array}{l}\text { Appropriate statistical models } \\
\text { which control for confounders }\end{array}$ & Red & $\begin{array}{l}\text { One can only infer that independent t-tests were used as the authors } \\
\text { do not clearly report it. T-tests without controlling for co-variates } \\
\text { would be problematic }\end{array}$ \\
\hline \multirow[t]{3}{*}{$\begin{array}{l}\text { Kelley } \\
201768\end{array}$} & Reporting bias on author level & Orange & $\begin{array}{l}\text { Sample characteristics are not well described. Statistical analyses and } \\
\text { models are described, p-values are reported but t-tests and also } \\
\text { Cohens-coefficients are not always reported }\end{array}$ \\
\hline & Responder bias on student level & Green & Grades are objective \\
\hline & Blinding & Green & Data retrieved from archive \\
\hline
\end{tabular}


medRxiv preprint doi: https://doi.org/10.1101/2021.05.19.21252346; this version posted May 20, 2021. The copyright holder for this preprint (which was not certified by peer review) is the author/funder, who has granted medRxiv a license to display the preprint in perpetuity.

It is made available under a CC-BY-NC-ND 4.0 International license.

\begin{tabular}{|l|l|l|l|}
\hline & $\begin{array}{l}\text { (Dis)similarity of baseline } \\
\text { characteristics }\end{array}$ & Red & Not reported \\
\hline $\begin{array}{l}\text { Appropriate statistical models } \\
\text { which control for confounders }\end{array}$ & Red & No. Simple t-tests without covariates \\
\hline Control group present & Orange & $\begin{array}{l}\text { Comparison with a national sample which is probably not a (gender) } \\
\text { matched control group }\end{array}$ \\
\hline
\end{tabular}

